\title{
KULEUVEN
}

\section{International student exchange and academic performance}

Dirk Czarnitzki, Wytse Joosten and Otto Toivanen 


\title{
International Student Exchange and Academic Performance
}

\author{
Dirk Czarnitzki $^{\mathrm{a}, \mathrm{b}, \mathrm{c}}$, Wytse Joosten ${ }^{\mathrm{a}, \mathrm{b}}$ and Otto Toivanen ${ }^{\mathrm{c}, \mathrm{d}, \mathrm{e}, \mathrm{f}}$ \\ ${ }^{\text {a }}$ KU Leuven, Dept. of Management, Strategy and Innovation, Leuven, Belgium \\ ${ }^{\mathrm{b}}$ Centre for R\&D Monitoring (ECOOM), Leuven, Belgium \\ ${ }^{\mathrm{c}}$ Centre for European Economics Research (ZEW), Mannheim, Germany \\ ${ }^{\mathrm{d}}$ Aalto University School of Business, Helsinki, Finland \\ ${ }^{\mathrm{e}}$ Helsinki Graduate School of Economics, Helsinki, Finland \\ ${ }^{\mathrm{f}}$ KU Leuven, Dept. of Economics, Leuven, Belgium
}

This version: January 2021

\begin{abstract}
International student exchange has become an important part of university-level studies and the EU plans to increase it significantly. We analyze how international student exchange affects students' academic human capital. Using detailed studentlevel data from four faculties (Economics and Business, Law, Engineering and Science) of a large Belgian public university we find that, on average, exchange students lose $7 \%$ in terms of grades relative to their non-mobile peers, but less so in Erasmus-facilitated exchange. Since students' academic performance is an important factor in companies' hiring decisions, participation in international exchange seems to have a non-negligible impact on labor market outcomes.
\end{abstract}

Keywords: $\quad$ Exchange programs; student mobility; academic performance JEL-Classification: I23, I26, J24

E-mail addresses: dirk.czarnitzki@kuleuven.be wytse.joosten@kuleuven.be otto.toivanen@aalto.fi

\footnotetext{
Acknowledgements:

The authors would like to thank the seminar participants at the Ph.D. workshops in Turin and Mannheim and the Competition and Innovation Summer School for helpful comments and suggestions, the Research Coordination Office (DOC) of KU Leuven for funding and Cel Datamanagement of KU Leuven for the provision of the data. We are especially grateful to Kurt De Wit, and the faculty exchange coordinators: Isabelle Benoit, Pascale Conard, Isabel Lauweres, Lieve Smets and Veerle Timmermans.
} 


\section{Introduction}

A choice of increasing prominence for university students is international student exchange which exposes the student to a foreign culture and a different school at the cost of uprooting the student from her regular environment and study plan. The European Commission (2015) reports that more than one million students participated in the Erasmus program within a five-year time period (2009-2013), which is about 5\% of all tertiary education students. This number will increase as the countries participating in the Bologna Process have agreed that by 2020 at least $20 \%$ of graduates should have spent part of their study or training abroad (van der Wende, 2000) and in 2018, the European Commission decided to double the budget of the Erasmus program to 30 billion euros for the period $2021-2027 .{ }^{1}$ Given the individual and societal investments in these programs, understanding the private and social costs and benefits of such exchange programs is highly important both for students and higher education institutions as well as for policy makers. In order to contribute to a more thorough understanding of the effects of exchange, we examine the causal impact of an international exchange on a student's human capital, as measured by academic performance.

Despite the widespread belief in the positive effects of student exchange programs, empirical evidence is scarce. With some notable exceptions (e.g. Di Pietro, 2012, 2015; Parey and Waldinger, 2011; Sorrenti, 2017), the vast majority of studies rely on correlations to report a positive effect of exchange on a student's personal characteristics, language skills and labor market mobility. ${ }^{2}$ However, as mobile students differ in many ways from non-mobile students, it is highly likely that unobserved heterogeneity, in terms of e.g. motivation and ability, affects both the decision to go on exchange as well as the measured outcome(s).

\footnotetext{
1 see https://ec.europa.eu/programmes/erasmus-plus/news/commission-adopts-proposal-next-erasmus-programme-20212027_en, accessed May 2nd, 2019.

${ }^{2}$ Papers discussing these topics are e.g. Brandenburg et al. (2014), Hadis (2005) and Teichler (2002)
} 
The net impact of exchange on academic performance is, a priori, unknown. Participation in exchange broadens a student's mindset, increases her language skills and confronts her with a different teaching style (e.g. Brandenburg et al., 2014; Sorrenti, 2017). If these factors are positively correlated with learning, exchange would increase a student's academic performance. Alternatively, the uprooting of a student caused by the exchange also introduces barriers to learning. A new environment, linguistic and cultural barriers and a possibly lower quality of education abroad may disrupt the student's learning and lead to a decreased level of academic human capital. Such effects may be exacerbated by poor planning of the curriculum during the exchange.

To shed light on the effect of international exchange on acquired human capital which in the human capital theory (Becker, 1964; Mincer, 1958) improves individual productivity, we leverage data from a large, continental European university, the KU Leuven in Belgium. ${ }^{3}$ Focusing on four of the largest faculties (Economics and Business, Law, Engineering and Science), we construct a dataset containing detailed information on 5,138 students, 950 (18.5\%) of whom went on exchange. The data include information on timing and type of international exchange, individual grades, the study program, socioeconomic status and gender for five different student cohorts, starting their studies in years 2006 to 2010. We also make use of a student survey and interviews we conducted with the personnel managing the exchange programs to both specify our model and to interpret our results. Grades are the system through which universities measure the (accumulation of) human capital. ${ }^{4}$ Accordingly, we use grades as our measure of human capital acquisition.

\footnotetext{
${ }^{3}$ Data on KU Leuven has been used in a number of previous studies, e.g. Debackere (2000).

${ }^{4}$ Roth and Clarke (1998) provide a meta-analysis of the relation between wage and grades and find robust positive correlations between these variables.
} 
Students going on exchange are selected based on academic performance. Descriptive statistics show that exchange students differ from non-mobile students in terms of observable characteristics, like socio-economic status and gender. We therefore match exchange students with similar non-mobile peers using Propensity Score Matching and restrict the sample to matched individuals. To control for unobservable characteristics that may be correlated with both student performance and selection into exchange, we resort to a conditional difference-indifference (cDID) analysis, where we compare grades obtained before the exchange with those obtained after the exchange at the home institution. ${ }^{5}$ The results indicate that, on average, exchange students lose $7 \%$ in terms of their final grade outcome relative to non-mobile peers. Some $12 \%$ of exchange students fail to reach the next level of distinction upon graduation because of exchange. Our findings further suggest that the treatment effect is heterogeneous in terms of the student's home faculty (i.e. field of study), the type of exchange and the host institution. Of particular interest is the finding that students going on exchange through the Erasmus program do not, with the exception of engineering students, suffer a decrease in their performance. This might hint to a partial success of the Bologna process which makes study programs more comparable among participating Member States. Furthermore, a less negative impact is found for students leaving for a destination that is not better ranked than their home faculty. Our finding that at the Faculty of Law students going on exchange does not have a negative impact on subsequent student performance is of university-policy interest: the Faculty of Law stood out from the other faculties in that the curriculum during the exchange is carefully designed.

\footnotetext{
${ }^{5}$ As grading standards differ across countries and institutions, we omit all courses taken at the host institution of the exchange. We therefore do not consider Grade Point Averages (GPAs), but strictly only grades obtained at the home institution, both before the exchange and after its completion.
} 
We provide evidence supporting the key identifying assumption of common pre-trends for the treatment and control groups. We investigate the robustness of our results to the choice of the control group: our results are robust when we narrow down the control group to those students that applied to go on exchange, but were not selected. In terms of motivation, these students are most comparable to the treated ones. In addition, we explore the cultural distance between the home and host country and the experience level of exchange coordinators.

Our analysis provides empirical evidence that participation in international exchange might harm a student's academic performance, and hence academic human capital and subsequent labor market outcomes. Our measure obviously does not capture the overall impact of exchange, nor does it aim to do so. Although we believe that academic performance is an important aspect of human capital, we also agree that exchange affects a student's personal development, and hence human capital, in many (different) ways. Further research is needed to estimate the overall impact of exchange on human capital levels. At a policy level, our results suggest a hitherto unidentified opportunity cost for student exchange that universities may avoid by (more) careful planning of the curriculum during the exchange, and that the structure provided by the Erasmus program seem to ameliorate the negative impact of exchange.

In terms of existing literature, Parey and Waldinger (2011) use aggregate German data to show that going on exchange increases the probability of working abroad. Di Pietro (2012) confirms this finding using data on Italian graduates. The impact of participation in exchange on the probability of employment is mixed. Di Pietro (2015) shows that, among Italian graduates, international exchange enhances the probability of employment three years after graduation.

Turning to descriptive work, Cisneros-Donahue et al. (2012) and Luo and JamiesonDrake (2015) rely on a student's self-reported learning or self-assessment to examine the association of study abroad with academic performance, but do not attempt to identify the 
causal effect of student exchange. Meya and Suntheim (2014) investigate the effect of a temporary study-related stay abroad on academic performance by comparing the Bachelor's grades of exchange students with those of similar non-mobile students. They find a significant increase in a student's final grade because of exchange, driven mostly by a selective transfer of grades. In other words, students only keep those grades they obtained abroad that improve their average result. Finally, Messer and Wolter (2007) and Wiers-Jenssen (2011) argue that mobile students obtain better grades than non-mobile students. This argument is supported by our data, as we find that mobile students obtain significantly better results, both before leaving for and after returning from exchange.

The remainder of this paper is organized as follows. Section 2 describes the different exchange programs at the faculties of interest. In section 3 we present an overview of the data, including summary statistics and a description of the main variables. The research methodology, empirical findings and sensitivity analyses are presented and discussed in section 4 where we also detail what we learned from discussions with the exchange administrators. In section 5 we discuss our findings, and section 6 concludes.

\section{Exchange programs at KU Leuven}

Our data stem from KU Leuven, which ranks in the top 15 of European universities in terms of research and education and within the top 100 in the world. ${ }^{6}$ Today KU Leuven comprises sixteen faculties. We focus on four of the largest ones at the main Leuven campus: Economics and Business, Law, as well as Engineering and Science. The total number of students at these faculties is round 7,500 for Bachelor programs and a little above 6,000 for Masters, which is $40 \%$ of all Bachelor and Master students at the main campus. Ever since the start of the Erasmus

\footnotetext{
${ }^{6}$ We consider the QS World University Rankings, the Academic Ranking of World Universities (Shanghai Ranking), the Ranking Web of Universities, and Times Higher Education: World University Rankings. KU Leuven was founded in 1425 and is one of the oldest universities in Europe.
} 
program, founded in 1987, KU Leuven has encouraged and supported international mobility among students and staff. Our understanding is that the international exchange arrangements at KU Leuven are representative of such arrangements in European universities.

\subsection{The academic program at KU Leuven}

The academic program at KU Leuven is representative of those in many European countries. Conditional on having obtained a secondary school degree, a student can register for a Bachelor program at KU Leuven. ${ }^{7}$ A Bachelor program is composed of at least 180 ECTS (European Credit Transfer and Accumulation System $^{8}$ ) credits and is designed to be completed within 3 academic years. After obtaining a Bachelor's degree, a student can pursue a Master's degree, which consists of 60 or 120 ECTS credits, depending on the field of study.

\subsection{Exchange opportunities}

Exchange programs are organized at faculty levels, with every faculty having its own rules and destinations. At the faculties of interest, a student has two opportunities to go on exchange: The first one is during her $3^{\text {rd }}$ Bachelor's year (Faculty of Economics and Business) or $1^{\text {st }}$ Master's year (other faculties); the second opportunity is in her $2^{\text {nd }}$ Master's year. These opportunities are not mutually exclusive and almost $3 \%$ of students go on exchange twice (see Section 3). The focus in this paper is on the first exchange opportunity.

Every faculty has certain criteria for a student to be eligible to go on exchange. The exact eligibility criteria differ over the faculties, but all are related to academic performance,

\footnotetext{
${ }^{7}$ A student can enroll into every study program conditional on having obtained a secondary school degree, except for the study program in Medicine and Dentistry, where she should pass a qualification exam first.

8 Cf. https://ec.europa.eu/education/resources-and-tools/european-credit-transfer-and-accumulation-systemects_en.
} 
focusing on a student's grades and her study efficiency. ${ }^{9}$ We use these criteria to select, separately for each faculty, a group of non-mobile students that is most similar to the treatment group of students who go on exchange. While the criteria are based on academic performance, they do not allow using a regression discontinuity design, as will explain below.

One year before the exchange takes place, the eligible student files an official application, indicating her preferred choice(s) of destination. The exchange coordinator (i.e., the person in charge of the exchange program at the faculty) then decides which student(s) can go to which host university. The decision is based on students' preferences, language knowledge, grades and motivation, the latter of which is decided on by an informal interview or a motivation letter accompanying the application. At the Economics and Business Faculty as well as the Law Faculty the number of applicants exceeds the number of exchange places. This allows splitting the control group of eligible, non-mobile students into two distinct groups. The first group consists of students who did not apply for exchange. The second group includes all students that applied to leave, but were not selected or did not go in the end for private reasons. In the following we will refer to the latter group of students as the non-mobile applicants. In terms of motivation, these students are the closest to the exchange students. The selection process is less formal at the Faculty of Science and Faculty of Engineering and more focused on finding a host destination for each applicant. In these two faculties the number of non-mobile applicants is too small to allow a separate analysis.

Students can apply for a destination outside the EU or leave for a university within the EU as part of the Erasmus program. The goal of the Erasmus program is to increase mobility among European students and staff in order to enhance employability and lifelong learning, and

\footnotetext{
${ }^{9}$ Study efficiency is the proportion of ECTS credits a student obtained at the end of the academic year out of the total amount of ECTS credits she registered for. An academic year consists of 60 ECTS credits, divided over a number of courses. To obtain the credits for a course, the student must pass (i.e., score at least 10 out of 20).
} 
promote the European values of respect, freedom, democracy and equality. ${ }^{10}$ Over the years, several policy changes were introduced, like the ECTS (European Credit Transfer System) and the Bachelor-Master system (Van der Wende, 2000; Wächter, 2004) in order to increase participation in exchange by removing obstacles and enabling credit recognition.

\subsection{Descriptive statistics of the KU Leuven exchange programs}

In this sub-section, we highlight some key descriptive statistics of the exchange programs. Detailed statistics are provided in Table 1 and in Table A.1 in the Appendix. At the faculties of interest, 1,405 students participated in exchange within a five year time period, ${ }^{11}$ which is $27.3 \%$ of all eligible students. Out of these $802(57.1 \%)$ went on exchange in the $3^{\text {rd }}$ Bachelor's or $1^{\text {st }}$ Master's year, 455 (32.4\%) left in the $2^{\text {nd }}$ Master's year, and $148(10.5 \%)$ participated twice.

Our analysis focuses on the $950(=802+148)$ students that participated in exchange with the $1^{\text {st }}$ opportunity. The number of exchange students among eligible students is highest at the Faculty of Economics and Business, reaching 465 students (29.6\%). At the Law Faculty the number equals 277 (20.3\%), whereas it is only 152 (9.7\%) at the Faculty of Engineering and $56(8.9 \%)$ at the Science Faculty.

In terms of the host university, destinations within Europe, as part of the Erasmus program, are most popular. More than three quarters of students (814 students or $85.7 \%$ ) participating in exchange stay within Europe. The most popular destination country differs across faculties. While most economics and law students leave for France, engineers mostly go on exchange to Switzerland and Spain, and science students opt for Sweden. Looking at the host institution's ranking, $15 \%$ of exchange students left to a host institution that has a better ranking than her home university's faculty.

\footnotetext{
${ }^{10} \mathrm{https}: / / w w w . e r a s m u s p l u s . i s / m e d i a / e x p e r t-t r a i n i n g-e p l u s / E r a s m u s+-B r i e f i n g-S h e e t . p d f$

${ }^{11}$ The database includes students starting their studies in the academic years 2006-2007 to 2010-2011
} 


\section{Data}

The database used for the empirical analysis contains detailed information on almost 5,800 students that obtained both a Bachelor's and a Master's degree at KU Leuven. The available data include information on the Bachelor's and/or Master's program a student entered; background information such as year of birth, gender, nationality and parents' degree; grades, both for individual courses as well as final Bachelor's and Master's grades; and exchange information if the student applied to go abroad. The data allow us to investigate five different cohorts of students, starting their studies in the academic years 2006-2007 to 2010-2011.

Table 1. Number of students going on exchange

\begin{tabular}{|c|c|c|c|c|c|c|c|c|c|}
\hline \multicolumn{5}{|c|}{ Faculty of Economics and Business } & \multicolumn{5}{|c|}{ Faculty of Law } \\
\hline & & \multicolumn{3}{|c|}{ Exchange in $2^{\text {nd }}$ Master } & & & \multicolumn{3}{|c|}{ Exchange in $2^{\text {nd }}$ Master } \\
\hline & & No & Yes & Total & & & No & Yes & Total \\
\hline \multirow{3}{*}{$\begin{array}{l}\text { Exchange in } \\
3^{\text {rd }} \text { Bachelor }\end{array}$} & No & 859 & 245 & 1104 & \multirow{3}{*}{$\begin{array}{l}\text { Exchange } \\
\text { in } 1^{\text {st }} \\
\text { Master }\end{array}$} & \multirow{3}{*}{$\begin{array}{l}\text { No } \\
\text { Yes } \\
\text { Total }\end{array}$} & 981 & 107 & 1088 \\
\hline & Yes & 324 & 141 & 465 & & & 273 & 4 & 277 \\
\hline & Total & 1183 & 386 & 1569 & & & 1254 & 111 & 1365 \\
\hline
\end{tabular}

\begin{tabular}{|c|c|c|c|c|c|c|c|c|c|}
\hline \multicolumn{5}{|c|}{ Faculty of Engineering } & \multicolumn{5}{|c|}{ Faculty of Science } \\
\hline & & \multicolumn{3}{|c|}{ Exchange in $2^{\text {nd }}$ Master } & & & \multicolumn{3}{|c|}{ Exchange in $2^{\text {nd }}$ Master } \\
\hline & & No & Yes & Total & & & No & Yes & Total \\
\hline \multirow{3}{*}{$\begin{array}{l}\text { Exchange in } \\
1^{\text {st }} \text { Master }\end{array}$} & No & 1353 & 68 & 1421 & \multirow{3}{*}{$\begin{array}{l}\text { Exchange } \\
\text { in } 1^{\text {st }} \\
\text { Master }\end{array}$} & No & 540 & 35 & 576 \\
\hline & Yes & 150 & 2 & 152 & & Yes & 55 & 1 & 56 \\
\hline & Total & 1503 & 70 & 1573 & & Total & 595 & 36 & 631 \\
\hline
\end{tabular}

As already mentioned, we discard all students that are not eligible to go on exchange (11\%), according to the faculty-specific rules. ${ }^{12}$ This leaves us with 5,138 students, among whom 950 (18.49\%) went on exchange in the $3^{\text {rd }}$ Bachelor's (Faculty of Economics and Business) or $1^{\text {st }}$ Master's year (other faculties). In the following we will refer to these exchange students as our

\footnotetext{
${ }^{12}$ As indicated before, eligibility rules are related to the student's grades obtained and cumulative study efficiency (i.e., the relative number of credits the student obtained out of the total amount of credits she registered for).
} 
treatment group. An important observation is that 148 students of the treatment group left on exchange twice, also leaving in the $2^{\text {nd }}$ Master's year. Most of these students are in the Faculty of Economics and Business, with only 7 students in the other three faculties going on exchange twice. An overview of the exchange students and eligible non-mobile students per faculty can be found in Table 1 .

We have roughly the same number of observations on eligible students for both the Faculty of Engineering and Faculty of Economics and Business at more than 1,500; the number of observations for the Faculty of Law is somewhat below 1,400, and for the Faculty of Science provides a little over 600 observations.

\subsection{Variables}

Our main research interest is the effect of participation in international exchange on a student's academic performance. We therefore construct our main treatment variable as an indicator variable, Exchange, that takes value one when a student went on exchange either in the $3^{\text {rd }}$ Bachelor's or the $1^{\text {st }}$ Master's year and zero otherwise.

When calculating students' average grades, we noticed that the grades obtained on exchange differ significantly from KU Leuven grades (Table A.2 in Appendix). This has two important implications. First, we construct the dependent variable, Grade difference, as the weighted average grade of courses a student registered for strictly after exchange (Grade ${ }_{1}$ ) minus the weighted average grade of the courses before the application for exchange $\left(\right.$ Grade $\left._{0}\right) .{ }^{13}$ As weights we use the ECTS points for each course. We exclude the grades obtained in the year of exchange and between the application and the start of the exchange year. More concretely, for the Faculty of Economics and Business we discard all grades from the $2^{\text {nd }}$

\footnotetext{
${ }^{13}$ At $\mathrm{KU}$ Leuven a criterion-referenced grading system is used, i.e., students are graded according to a fixed set of predetermined criteria.
} 
and $3^{\text {rd }}$ Bachelor's year, and for the other faculties we exclude grades from the $3^{\text {rd }}$ Bachelor's and the $1^{\text {st }}$ Master's year. Thus, Grade $e_{0}$ measures the grades in the first Bachelor's year for the Faculty of Economics and Business, and the grades in first two Bachelor's years for the other faculties. ${ }^{14}$ In similar vein, Grade $_{1}$ measures the grade in the (one or two) years of the Master's degree for the Faculty of Economics and Business, and the grades in the second year of the Master's degree for the other faculties. Second, as mentioned before, several students went on exchange in the final Master's year. We create a dummy variable, Exchange final year, which equals one if the student went on exchange in her final Master's year and is zero otherwise. We include this variable since grade averages obtained during exchange are not representative to KU Leuven grades (see Table A.2 in the Appendix).

We observe five different cohorts of students. We construct time dummies, Cohort FE, referring to the different starting years at KU Leuven, with the cohort of 2006-2007 being the reference cohort.

We use the following student characteristics in our analysis: a dummy variable Female indicates whether a student is female. The variable Foreign equals one if the student does not have a Belgian nationality. The dummy variable Scholarship indicates whether or not the student got a scholarship from the Flemish government. The latter acts as a proxy for financial resources of the family, since only students whose parents' income is below a certain level can apply for it. ${ }^{15}$ Note that the scholarship is independent of an exchange grant. Students can apply for a scholarship every academic year and, when leaving for exchange, receive an exchange grant on top of that. The age of a student when starting a Bachelor's program is measured by

\footnotetext{
${ }^{14}$ Students at KU Leuven are graded on a scale from 0 to 20, where a score of at least 10/20 means that the student has passed for the course. For this study however, we rescale their grades to a scale from 0 to 100, as this allows us to look at the differences into more detail.

${ }^{15}$ The exact criteria to be applicable for a scholarship can be found on https://www.kuleuven.be/studentenvoorzieningen/socialedienst/studiefinanciering/studietoelage_vlgem.html.
} 
the variable Age. Variables Univ degree father and Univ degree mother are dummy variables which equal one if the student's father or mother, respectively, has a university degree and zero otherwise.

Table 2. Variable definitions

\begin{tabular}{|c|c|}
\hline Variable & Description \\
\hline Exchange & $\begin{array}{l}\text { Dummy indicating whether the student went on exchange in her } 3^{\text {rd }} \text { Bachelor's (Faculty of } \\
\text { Economics and Business) or } 1^{\text {st }} \text { Master's year (other faculties) }\end{array}$ \\
\hline Grade $_{0}$ & Weighted average grade of the student before application for exchange \\
\hline Grade $_{1}$ & Weighted average grade of the student after exchange \\
\hline Grade difference & Difference in grade $_{1}$ and grade 0 \\
\hline Exchange final year & Dummy indicating whether the student went on exchange in her final Master's year \\
\hline Cohort FE & Vector of dummies referring to the year the student started at KU Leuven \\
\hline Faculty FE & Vector of dummies referring to the student's faculty \\
\hline Female & Dummy indicating whether the student is female \\
\hline Foreign & Dummy indicating whether the student has a nationality other than Belgian \\
\hline Age & Age of the student when starting at KU Leuven \\
\hline Scholarship & $\begin{array}{l}\text { Dummy indicating whether the student received a scholarship (i.e., financial compensation) from } \\
\text { the government to enter higher education }\end{array}$ \\
\hline Univ degree father & Dummy indicating whether the student's father has a university degree \\
\hline Univ degree mother & Dummy indicating whether the student's mother has a university degree \\
\hline Erasmus & $\begin{array}{l}\text { Dummy indicating whether the student went on exchange within Europe, as part of the Erasmus } \\
\text { program }\end{array}$ \\
\hline Better ranked & Dummy indicating whether the host institution has a better ranking than the KU Leuven faculty \\
\hline
\end{tabular}

\subsection{Descriptive statistics}

Exchange students have a better socioeconomic background in terms of financial resources (West, 2001) and the educational level of the student's mother (West, 2001, Messer and Wolter, 2007 and Wiers-Jenssen, 2011). Our data confirm these findings. Table 3 shows that exchange students are less likely to receive a scholarship (9\% vs. 14\%), which acts as a proxy for financial resources of the family. The percentage of students whose mother has a university degree equals $46 \%$ for exchange students, while only $29 \%$ for non-mobile students. In addition, we observe that the proportion of females is higher among mobile students (55\% vs. $42 \%)$. The percentage of non-Belgian students equals about $2 \%$ for both mobile and non-mobile students. 
Table 3. Summary statistics for mobile and non-mobile students

\begin{tabular}{l|cccc|cccc|cc}
\hline & \multicolumn{3}{|c|}{ Mobile students } & \multicolumn{3}{c|}{ Non-mobile students } & \multicolumn{2}{c}{$\begin{array}{c}\text { Diff. mobile and non- } \\
\text { mobile students }\end{array}$} \\
\hline Variable & Mean & Std.Dev. & Min & Max & Mean & Std.Dev. & Min & Max & Mean & Std.Er. \\
\hline Female & 0.55 & 0.50 & 0 & 1 & 0.42 & 0.49 & 0 & 1 & $0.14 * * *$ & 0.02 \\
Foreign & 0.02 & 0.13 & 0 & 1 & 0.02 & 0.13 & 0 & 1 & 0.00 & 0.00 \\
Age & 18.06 & 0.55 & 16 & 27 & 18.11 & 0.83 & 17 & 51 & $-0.05^{* *}$ & 0.02 \\
Scholarship & 0.09 & 0.29 & 0 & 1 & 0.14 & 0.34 & 0 & 1 & $-0.04 * * *$ & 0.01 \\
Univ degree father & 0.59 & 0.49 & 0 & 1 & 0.40 & 0.49 & 0 & 1 & $0.19 * * *$ & 0.02 \\
Univ degree mother & 0.46 & 0.50 & 0 & 1 & 0.29 & 0.45 & 0 & 1 & $0.17 * * *$ & 0.02 \\
\hline
\end{tabular}

Exchange students thus differ in several observable traits from non-mobile students. We deal with this by matching exchange students to similar non-mobile students on observable characteristics: socioeconomic status, gender, nationality, age and time cohort. Since the treated students only differ from the non-treated ones in terms of the treatment (here exchange), any differences in the outcome(s) can be assigned to the treatment (Heckman et al., 1998). We use Propensity Score Matching (PSM) to group exchange students with their two nearest nonmobile peers based on the propensity score, which estimates the conditional probability of being treated, relative to observable pre-treatment characteristics (Rosenbaum and Rubin, 1983; Becker and Ichino, 2002):

$$
\mathrm{p}(\mathrm{X})=\operatorname{Pr}(\mathrm{A}=1 \mid \mathrm{X})=\mathrm{E}(\mathrm{A} \mid \mathrm{X})
$$

The variable A denotes the treatment, exchange, and $\mathrm{X}$ is the set of observable student characteristics. Table A.3 in the Appendix shows the outcomes of a multivariate analysis that estimates the probability to participate in an exchange program. The outcomes show that a student's socio-economic status and her gender have a significant impact on the likelihood to leave on exchange. We also observe strong differences according to the student's faculty. Restricting the estimation sample to matched observations reduces the size of the control group 
from over 4,000 to around 500, but we gain in terms of comparability of the treated and control group individuals.

\section{Analysis}

Above we showed that mobile students differ from non-mobile peers in terms of socioeconomic status and gender. Important for our main analysis is that exchange students also obtain higher grades than non-mobile students. Figures A.1-A to A.1-D in the Appendix show Kernel density estimated of the grade distribution for each faculty, separately for grades before and after the exchange. An overview of the students' average grades is presented in Table 4, columns (1) to (4). The table and the Kernel density estimates include all matched observations, but exclude students who went on exchange in their final Master's year. As already explained, we exclude these because students' grades obtained at the host institution are not comparable to KU Leuven grades.

Overall, the average grade of mobile students is $64.42 \%$ before the exchange, while the corresponding average is $62.28 \%$ for their non-mobile peers (column 1 ). The difference equals 2.14 percentage points (pp) and is statistically significant at the $1 \%$ level. This difference is as expected, because students are selected for exchange on their language skills and grades. After the exchange the average grades equal $72.16 \%$ and $71.44 \%$ for mobile and non-mobile students respectively (column 3). When comparing the difference in grades over time in column (5) our dependent variable, exchange students improve $7.74 \mathrm{pp}$, compared to $9.15 \mathrm{pp}$ for nonmobile students. Thus, the statistically significant simple difference-in-difference estimate equals -1.41 pp (column 5), indicating that, on average, exchange students lose about 1.4 grade points relative to their non-mobile peers. 
Table 4. Grades obtained before and after exchange

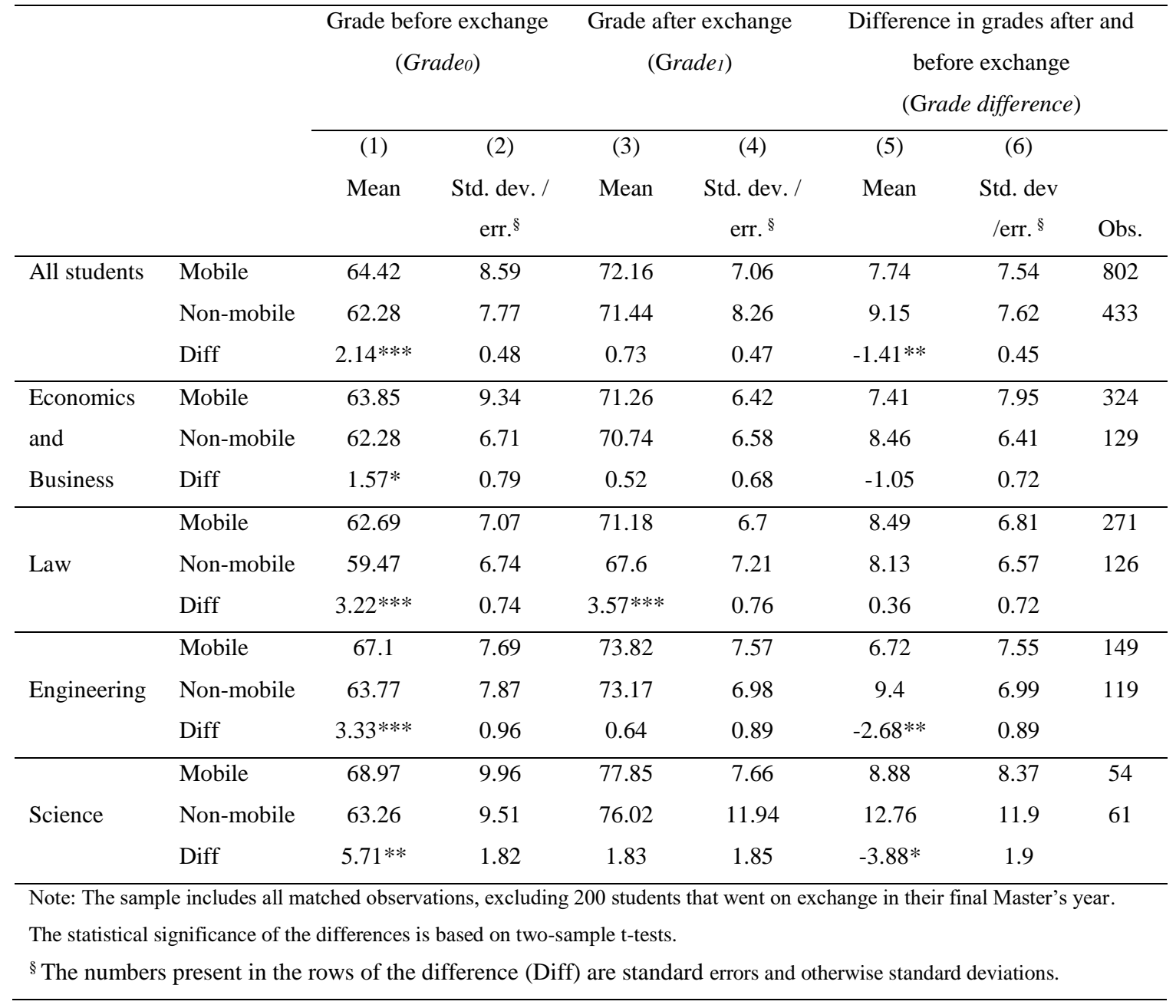

We then turn to the faculty-specific results. At the Faculties of Economics and Business and Law, the difference-in-difference estimate equals respectively -1.05 and 0.36 percentage points (column 5). Both estimates are statistically insignificant, suggesting no difference between exchange and non-mobile students. At the Faculties of Engineering and Science we observe a negative impact, equal to -2.68 and -3.88 percentage points. The initial analysis thus suggests that students "pay" for an exchange in the form of lower grades at the Faculties of Engineering and Science, and that second, there may be important differences between the faculties. We take these differences into account in our econometric analysis. 


\subsection{Econometric model}

We use a conditional difference-in-difference model to estimate the impact of international exchange on academic performance.

$$
\begin{gathered}
\text { Grade difference }_{i}=\alpha_{1}+\sum_{f} \text { Faculty }_{f}+\delta_{1} \cdot \text { Exchange }_{i} \\
+\delta_{2} \cdot \text { Exchange final year }_{i}+\sum_{f} \delta_{3} \cdot \text { Exchang }_{i} \cdot \text { Faculty }_{f} \\
+\Delta \beta_{1} \cdot F_{i}+\Delta \varepsilon_{i}
\end{gathered}
$$

The dependent variable, Grade difference ${ }_{i}$, is the difference in grades of student $i$ after and before exchange. The coefficient of the treatment variable Exchange $_{i}$ measures the average effect of an international exchange program on student $i$ 's academic performance, i.e., how going on exchange affects the grades of the exchange student relative to her non-mobile peers. The time-invariant effects, including unobserved student-specific characteristics, are differenced out.

As explained before, the dummy variable Exchange final year ${ }_{i}$ equals one when student $i$ went on exchange in her final Master's year, and thus captures possible differences in grading systems between KU Leuven and other higher education institutions. As control variables we include a gender dummy, Female $_{i}$, and variables related to socioeconomic status (vector $F_{i}$ ) comprising Univ degree father , Univ degree mother $_{i}$ and Scholarship . $_{\text {. }}$ Notice that in our set-up, the inclusion of these variables allows for heterogeneous trends in grades. To allow for differences across the faculties, we include faculty dummies $\left(\right.$ Faculty $\left._{f}\right)$ and faculty-exchange $\left(\right.$ Exchange $_{i} \cdot$ Faculty $\left._{f}\right)$ interaction terms.

To estimate the causal impact of participation in exchange on students' academic performance we would ideally select random students to leave on exchange. However, students 
decide themselves whether or not to apply to go on exchange, and the exchange program administrators in the faculties choose among then applicants. We deal with this non-random selection using a difference-in-difference (DiD) approach. The key identifying assumption underlying the DiD estimates is the common trends assumption. It states that the average change in the comparison group represents the counterfactual change in the treatment group if there were no treatment. Since this assumption is by construction untestable, we look at pre-treatment trends among mobile and non-mobile students, focusing on grade development before selection into exchange. For the Faculty of Economics and Business, we focus on the difference in grades from $1^{\text {st }}$ to $2^{\text {nd }}$ semester in the $1^{\text {st }}$ Bachelor's year. For the other faculties the dependent variable is the difference from $1^{\text {st }}$ to $2^{\text {nd }}$ Bachelor's year. The results, presented in Table in the Appendix, show that the coefficient of the interaction of the trend with the exchange-dummy is not statistically different from zero, providing evidence that pre-trends are similar for mobile and non-mobile students. Although the institutional setting implies a positive selection into exchange in terms of grades, the trend in grades before exchange is independent of the treatment.

Many characteristics which are likely to affect the decision to go on exchange remain unobserved, such as motivation and ability. If these factors are correlated with the measured outcome, the coefficients of an OLS regression will be biased, as we would mistakenly attribute the effect of the unobserved heterogeneity to the exchange variable. Our cDID methodology allows filtering out the unobserved differences between exchange and non-mobile students to the extent that they are manifested in prior academic performance and/or constant in time. ${ }^{16}$ As stated earlier, we present the results of the matching regression in Table 5. In addition, an important robustness check that we perform is to restrict the control group to those students that

\footnotetext{
${ }^{16}$ An important concern is that unobserved student characteristics which are correlated with the selection into exchange and academic performance are not time-invariant. If, for example, motivation is positively correlated with participation in exchange and with students' grades, and if motivation increases over time, our main coefficient with exchange is biased upward.
} 
applied to go abroad, but were not selected, and are therefore most similar to the exchange students in terms of motivation.

A second, more extensive model includes different sources of heterogeneity in returns to the base model, in terms of the characteristics of the host destination. The second estimation equation is written as:

$$
\begin{gathered}
\text { Grade difference }_{i}=\alpha_{1}+\sum_{f} \text { Faculty }_{f}+\delta_{1} \cdot \text { Exchange }_{i} \\
+\delta_{2} \cdot \text { Exchange final year }_{i}+\sum_{f} \delta_{3} \cdot \text { Exchang }_{i} \cdot \text { Facult }_{f} \\
+\delta_{5} \cdot \text { Erasmus }_{i}+\delta_{6} \cdot \text { Better ranked }_{i}+\Delta \beta_{1} \cdot F_{i}+\Delta \beta_{2} \cdot \text { Female }_{i}+\Delta \varepsilon_{i}
\end{gathered}
$$

The Erasmus $_{i}$ variable equals one if student $i$ went on exchange within Europe, as part of the Erasmus program. ${ }^{17}$ Note that Erasmus $_{i}$ is an implicit interaction term with Exchange . $_{\text {. }}$ The coefficient reflects the differential in the impact for a student leaving to a host institution within Europe, compared to her peers going on exchange outside of Europe. ${ }^{18}$ As indicated before, the European Commission has invested in the transparency and comparability of higher education programs across Europe (e.g. the introduction of ECTS and the Bachelor-Master system). If these interventions enable students to choose better courses at the host institution (i.e., a better fit in terms of content and course load with the courses they would have taken at KU Leuven), this will be translated into a positive effect of exchange within Europe, versus outside. In addition, one can argue that the cultural differences between Belgium and other European countries are smaller compared to differences with countries outside of Europe. If

\footnotetext{
${ }^{17}$ In our sample 814 out of 950 exchange students $(85.7 \%)$ participate in the Erasmus program. Exact numbers for each Faculty can be found in Table in the Appendix.

${ }^{18}$ The countries outside of Europe students can go on exchange to are Australia, Brazil, Canada, China, Hong Kong, Mexico, Singapore, the United States and South Africa
} 
cultural distance induces a barrier to learning, students leaving for Erasmus will learn more than those traveling farther away (culturally), which could increase academic performance after exchange.

The effect of the exchange might be different for students going on exchange to a top university. ${ }^{19}$ The high quality of the course level and content, as well as the high performance of peer students at the host institution could induce these exchange students to learn more, study harder and engage more seriously in their studies. This could have a positive impact on students' grades, also after returning to KU Leuven. Alternatively, barriers to learning might be higher at a top institute if the courses build on previous knowledge that the exchange student might lack. To investigate the differential in academic performance for students leaving to a top institute,

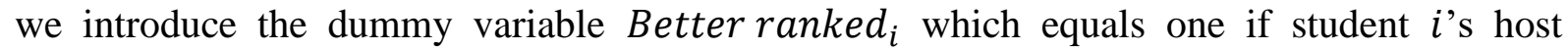
institution has a better ranking than KU Leuven. ${ }^{20}$

Our initial analysis in Table 4 suggests that the impact of participation in exchange may differ between the faculties of KU Leuven. We therefore perform also separate estimations for each faculty. A disadvantage of this approach is that the sample sizes decrease, which impacts the significance levels. This is especially true at the Faculty of Science, where we observe only 56 exchange students. Our starting point is therefore the pooled sample over all faculties. When using the pooled sample, we allow for faculty-specific heterogeneity through faculty dummies and faculty-exchange interaction terms.

\footnotetext{
${ }^{19}$ The number of exchange students leaving to a better ranked institution equals 139 out of 950 (14.6\%). Exact numbers for each Faculty can be found in Table in the Appendix.

${ }^{20}$ We look at the Academic Ranking of World Universities (Shanghai Ranking 2015), QS Ranking (2016) and Business School Ranking (2015) to compare the ranking of the host institution with KU Leuven. The exact method used can be found in Table in the Appendix.
} 


\subsection{Results}

We first report the results of the pooled model. In columns (1) and (2) of Table 5 we present the results of the conditional difference-in-difference model. Column (3) shows the results from an analysis where we restrict the control group to non-mobile applicants. The results for all eligible students are presented in column (4).

As shown in column (1), the main variable of interest, Exchange $e_{i}$, has a negative impact of about 1.14 percentage points (pp) on a student's grade difference at the Faculty of Economics and Business, our baseline faculty. This result is significant at the $10 \%$ level. The impact at the other faculties is not significantly different from our baseline result. The impact at the Law Faculty equals $-0.04 \mathrm{pp}(=-1.14+1.11)$, while exchange has a negative impact of $-2.55(=-1.14-1.40)$ pp at the Engineering Faculty, and $-2.44(=-1.14-1.30)$ pp at the Science Faculty.

Column (2) adds different sources of heterogeneity to the model. We find a more negative impact of exchange on the grade difference. The coefficient of Exchange in column (2) represents the impact for a student in the Faculty of Economics and Business going on exchange outside of Europe to an institution that is not better ranked than the KU Leuven faculty. This coefficient equals -4.08 and is significant at the $1 \%$ level. The effect of an exchange is found to be similar to the baseline result in the Faculties of Law and Science, while a more negative impact is observed for the Engineering Faculty.

Analyzing the coefficients of the control variables in column (2), we notice that going on exchange in the final Master's year increases a student's grade difference by $1.08 \mathrm{pp}$. This outcome, which is significant at the $10 \%$ level, supports our previous finding that the grades obtained on exchange are not similar and cannot be compared to those obtained at KU Leuven. The coefficient of Female equals 1.48 and is statistically significant at the $1 \%$ level. It shows 
that female students' grades improve more than those of male students when comparing the period before and after exchange.

Table 5. DiD estimation results

\begin{tabular}{|c|c|c|c|c|}
\hline $\begin{array}{l}\text { Estimation model } \\
\text { Control group }\end{array}$ & $\begin{array}{c}\text { CDiD } \\
\text { Matched observations }\end{array}$ & $\begin{array}{c}\text { CDiD } \\
\text { Matched observations }\end{array}$ & $\begin{array}{c}\text { DiD } \\
\text { Applicants } \\
\text { (FEB \& Law) }\end{array}$ & $\begin{array}{c}\text { DiD } \\
\text { All eligible students }\end{array}$ \\
\hline & (1) & (2) & (3) & (4) \\
\hline Exchange & $\begin{array}{l}-1.144 * \\
(0.609)\end{array}$ & $\begin{array}{c}-4.083 * * * \\
(0.845)\end{array}$ & $\begin{array}{c}-4.487 * * * \\
(0.929)\end{array}$ & $\begin{array}{c}-3.833 * * * \\
(0.714)\end{array}$ \\
\hline Exch. Law & $\begin{array}{c}1.106 \\
(0.915)\end{array}$ & $\begin{array}{c}0.771 \\
(0.920)\end{array}$ & $\begin{array}{c}-0.0600 \\
(1.327)\end{array}$ & $\begin{array}{c}0.437 \\
(0.620)\end{array}$ \\
\hline Exch. Engineering & $\begin{array}{l}-1.403 \\
(1.094)\end{array}$ & $\begin{array}{c}-1.894 * \\
(1.118)\end{array}$ & & $\begin{array}{c}-1.905^{* *} \\
(0.796)\end{array}$ \\
\hline Exch. Science & $\begin{array}{l}-1.296 \\
(1.849)\end{array}$ & $\begin{array}{l}-1.962 \\
(1.862)\end{array}$ & & $\begin{array}{c}-3.511 * * * \\
(1.220)\end{array}$ \\
\hline Law & $\begin{array}{l}-0.171 \\
(0.727)\end{array}$ & $\begin{array}{c}-0.0965 \\
(0.728)\end{array}$ & $\begin{array}{c}0.847 \\
(1.213)\end{array}$ & $\begin{array}{c}0.311 \\
(0.298)\end{array}$ \\
\hline Engineering & $\begin{array}{c}1.164 \\
(0.829)\end{array}$ & $\begin{array}{c}1.213 \\
(0.831)\end{array}$ & & $\begin{array}{c}1.003 * * * \\
(0.294)\end{array}$ \\
\hline Science & $\begin{array}{l}2.721 * \\
(1.475)\end{array}$ & $\begin{array}{l}2.788^{*} \\
(1.477)\end{array}$ & & $\begin{array}{c}4.335^{* * * *} \\
(0.421)\end{array}$ \\
\hline Exchange final year & $\begin{array}{c}0.680 \\
(0.580)\end{array}$ & $\begin{array}{l}1.079 * \\
(0.564)\end{array}$ & $\begin{array}{l}0.999 * \\
(0.555)\end{array}$ & $\begin{array}{c}0.758 * * \\
(0.320)\end{array}$ \\
\hline Female & $\begin{array}{c}1.647 * * * \\
(0.405)\end{array}$ & $\begin{array}{c}1.475 * * * \\
(0.402)\end{array}$ & $\begin{array}{c}1.159 * * \\
(0.491)\end{array}$ & $\begin{array}{c}0.892 * * * \\
(0.219)\end{array}$ \\
\hline Erasmus & & $\begin{array}{c}3.859 * * * \\
(0.759)\end{array}$ & $\begin{array}{c}3.955^{* * *} \\
(0.811)\end{array}$ & $\begin{array}{c}3.963 * * * \\
(0.755)\end{array}$ \\
\hline Better ranked & & $\begin{array}{l}-1.201 * \\
(0.675)\end{array}$ & $\begin{array}{c}-1.649 * \\
(0.859)\end{array}$ & $\begin{array}{c}-1.337 * * \\
(0.667)\end{array}$ \\
\hline Constant & $\begin{array}{c}8.509 * * * \\
(0.760)\end{array}$ & $\begin{array}{c}8.363 * * * \\
(0.754)\end{array}$ & $\begin{array}{c}8.330 * * * \\
(0.929)\end{array}$ & $\begin{array}{c}7.773 * * * \\
(0.338)\end{array}$ \\
\hline $\begin{array}{l}\text { SES (F) FE. } \\
\text { Cohorts FE. }\end{array}$ & $\begin{array}{l}\text { Yes } \\
\text { Yes }\end{array}$ & $\begin{array}{l}\text { Yes } \\
\text { Yes }\end{array}$ & $\begin{array}{l}\text { Yes } \\
\text { Yes }\end{array}$ & $\begin{array}{c}\text { Yes } \\
\text { Yes }\end{array}$ \\
\hline Obs. & 1,435 & 1,435 & 920 & 5,138 \\
\hline
\end{tabular}

An overview of the coefficients for the major interaction terms, including the statistical significance levels, is presented in Table 6. The coefficients of Erasmus and Better ranked 
reflect differences according to the host destination the student leaves for. We find that Erasmus exchange programs, compared to exchange programs outside of Europe, have a strong positive impact: The effect on the grade difference is $-4.08 \mathrm{pp}$ for an economics student going on exchange outside of Europe, but the effect is only $-0.22(=-4.08+3.86)$ pp for a similar student going on Erasmus exchange. We also observe that going to a better ranked institution than the KU Leuven faculty has a negative impact of $1.20 \mathrm{pp}$ on the grade difference, significant at the $10 \%$ level. The effect of participation in exchange on the grade difference equals -4.08 for a male economics student going to an institution that has a similar or lower ranking than his faculty, while the difference equals $-5.28(=-4.08-1.20)$ pp for a similar student going to a better ranked host institution. Interestingly, we notice a positive coefficient for female law students who leave on Erasmus exchange to an institution that is not better ranked than KU Leuven.

Table 6. Impact of exchange - Coefficients of major interaction terms

\begin{tabular}{|c|c|c|c|c|c|}
\hline & & $\begin{array}{c}\text { Economics and } \\
\text { Business }\end{array}$ & Law & Engineering & Science \\
\hline \multirow{2}{*}{ No Erasmus } & $\begin{array}{c}\text { Similar or lower ranked } \\
\text { institution }\end{array}$ & $\begin{array}{c}-4.083 * * * \\
{[0.00]}\end{array}$ & $\begin{array}{c}-3.312 * * * \\
{[0.00]}\end{array}$ & $\begin{array}{c}-5.977 * * * \\
{[0.00]}\end{array}$ & $\begin{array}{c}-6.045^{* * *} \\
{[0.00]}\end{array}$ \\
\hline & Better ranked institution & $\begin{array}{c}-5.284 * * * \\
{[0.00]}\end{array}$ & $\begin{array}{c}-4.513 * * * \\
{[0.00]}\end{array}$ & $\begin{array}{c}-7.178^{* * *} \\
{[0.00]}\end{array}$ & $\begin{array}{c}-7.246^{* * *} \\
{[0.00]}\end{array}$ \\
\hline \multirow{2}{*}{$\begin{array}{l}\text { Erasmus } \\
\text { exchange }\end{array}$} & $\begin{array}{c}\text { Similar or lower ranked } \\
\text { institution }\end{array}$ & $\begin{array}{l}-0.224 \\
{[0.72]}\end{array}$ & $\begin{array}{l}0.547 \\
{[0.43]}\end{array}$ & $\begin{array}{c}-2.118 * * \\
{[0.02]}\end{array}$ & $\begin{array}{l}-2.186 \\
{[0.22]}\end{array}$ \\
\hline & Better ranked institution & $\begin{array}{l}-1.425 \\
{[0.12]}\end{array}$ & $\begin{array}{l}-0.654 \\
{[0.47]}\end{array}$ & $\begin{array}{c}-3.319 * * * \\
{[0.00]}\end{array}$ & $\begin{array}{c}-3.387 * \\
{[0.07]}\end{array}$ \\
\hline
\end{tabular}

The heterogeneity in outcomes according to the student's faculty, the type of exchange (Erasmus vs. exchange outside of Europe) and the ranking of the host institution is also reflected in the impact of exchange on the student's level of achievement. The level of achievement or distinction is marked on every degree handed out by KU Leuven, and is an important mechanism for employers to distinguish among students. There are 5 levels of achievement: 1) 
passed, when the student's final grade $<68 \% ; 2$ ) distinction: when her grade $\geq 68 \%$ but $<77 \%$; 3) great distinction, when her grade $\geq 77 \%$ but $<85 \%$; 4) greatest distinction, when her grade $\geq$ $85 \%$ but $<90 \%$; and 5) greatest distinction with congratulations of the examination committee, when her grade $\geq 90 \%$. We compare the actual grade for every student with the grade she would have obtained had she not left on exchange. The latter is calculated at the faculty-level for different deciles of the grade distribution, and accounting for the type of exchange and the ranking of the host institution. The outcomes at faculty-level are presented in Table 7 in the Appendix. When we compare the actual level of distinction with the hypothetical one, we find that $12 \%$ of exchange students did not reach the next level of achievement because of exchange. Remarkably, at the Faculties of Economics and Business and Law 2.95\% of all exchange students jumped to the next distinction level because of exchange. They would not have done so, had they stayed at home.

\subsection{Robustness and sensitivity analysis}

In this subsection, we report a number of robustness tests and sensitivity analyses.

\subsubsection{Using only non-mobile applicants as controls.}

Exchange students also differ from non-mobile students in terms of unobservable characteristics. It is reasonable to assume that students who select themselves into the exchange program are the ones who expect to gain most from it. We account for this self-selection by restricting the control group to non-mobile applicants. These are the students that applied to go on exchange, but did not leave. In terms of motivation, they are most similar to the treatment group. As mentioned before, we are able to use the non-mobile applicants as a control group for the Faculties of Law and Economics and Business. At the other faculties, the group of students that applied to go, coincides (almost) perfectly with the group of exchange students. The results of the analysis with the restricted control group are presented in Table 5, column 
(3). The coefficient with Exchange is similar, though slightly larger in magnitude, and now equals -4.49 . In line with our previous results we observe a strong positive effect of Erasmus exchange compared to exchange outside Europe, and a negative impact for students leaving to a better ranked host institution.

\subsubsection{Conditioning on early grades}

An important concern is that exchange students' grades cannot improve (as) much because mobile students already obtain high(er) grades before leaving (see Table 4), so there is less room left for improvement. We adopt two approaches to deal with this concern. First, we estimate a quantile regression for each faculty separately to investigate whether the effect differs over different quantiles of students. We especially want to know whether the negative outcome is driven by the best students, as this would support our theory. The precision of the results is affected by the small faculty-specific samples. At the Faculties of Economics and Business (Figure A.2-A) and Science (Figure A.2-D) students in the lower part lose most, compared to non-mobile students. At the Faculty of Economics and Business, students in the upper part of the initial grade distribution seem not to lose. For the Faculty of Engineering (Figure A.2-C in the Appendix) no clear trend is visible. The results for the Faculty of Law (Figure A.2-B) suggest that the students at the upper bound (i.e., the best students) suffer most. We also estimate the relative instead of absolute increase in grades (Relative $G D_{i}$ ). We thereby take into account that it may be harder to improve one's grades when the initial grades are better. The relative grade difference is calculated as

$$
\text { Relative } G D_{i}=\frac{\text { Grade difference }_{i}}{\left(100-\text { Grade }_{O}\right)} \quad \text { if Grade difference } \text { G }_{i}>0
$$

and

$$
\text { Relative } G D_{i}=\frac{\text { Grade difference }_{i}}{\text { Grade }_{O}} \text { if Grade difference } \text { G }_{i}<0
$$


where Grade difference ${ }_{i}$ is the weighted average grade of courses a student registered for after exchange $\left(\right.$ Grade $\left._{1}\right)$ minus the weighted average grade of the courses before exchange (Grade $)_{0}$. The first line captures the extent to which the student has improved her grades, and relates it to how much they could be improved; hence the division by $100-$ Grade $_{O}$. The second line capture by what percentage the grades have worsened, this time relative to how much they could worsen; hence the division by $\operatorname{Grade}_{O}$. The results are presented in Table 8 in the Appendix. Our earlier findings are confirmed, showing a negative impact of exchange in general, with Erasmus having a less negative impact. The results of the quantile regressions and the relative progression in grades thus seem to reject the concern that mobile students' grades cannot improve (as) much as non-mobile students' grades, because of the absolute ceiling in students' grades.

\subsubsection{Selection out of KU Leuven}

Parey and Waldinger (2011) and Di Pietro (2012) find that students who go on exchange are more likely to work abroad after graduation. This raises the question whether an exchange program also affects a student's mobility during her academic studies. More concretely, students who go on exchange in the $3^{\text {rd }}$ Bachelor's year could be more likely to quit the university after obtaining a Bachelor's degree, in order to continue their study elsewhere. As only economics students are offered the possibility to leave on exchange during the Bachelor's years, we restrict the analysis to the Faculty of Economics and Business.

The outcomes, presented in Table (first stage) and A.9, column (4) (second stage) in the Appendix, support our hypothesis. Exchange students at the Faculty of Economics and Business are almost 5\% more likely to quit the university after obtaining a Bachelor's degree compared to non-mobile peers. To account for this selection effect, we use a Heckman selection model to estimate the effect of exchange conditional on obtaining a Master's degree at KU 
Leuven. In the first stage we estimate the probability of obtaining a Master's degree, including the final Bachelor's grade average for identification. We exclude the Bachelor's grade average and the student's age from the second stage. The second stage results are presented in column (4) of Table 9 in the Appendix. Our previous results persist: We find a negative coefficient of 4.16 with Exchange, significant at the $1 \%$ level, a positive coefficient for Erasmus and a negative coefficient for the Better ranked interaction term.

\subsubsection{Faculty-specific estimates}

The results using faculty-specific data, shown in Table 9 toTable in the Appendix, are similar to those presented above, although we lose in terms of significance, especially when introducing treatment effect heterogeneity into the models. The fact that the point estimates are comparable to those obtained with the pooled model suggests that reduced sample sizes may be the explanation. One important observation is that the coefficient of Erasmus approaches zero for the Faculties of Engineering and Science. This indicates that the positive impact of Erasmus in the pooled model might be mostly driven by the Faculties of Economics and Business and Law.

\subsection{Discussion}

Overall, the outcomes show that exchange has a negative effect on a student's academic performance. The impact differs across faculties and according to the type of exchange and the host institution's ranking. The effect is more positive at the Faculty of Law, for students going on an Erasmus exchange and for students leaving to an institution that is not better ranked than the KU Leuven's respective faculty. We have discussed these findings with the faculty exchange coordinators, and the following section introduces several mechanisms that might explain our results.

Whereas we observe a negative effect at the Faculties of Economics and Business, Engineering and Science, for the Faculty of Law our estimates show that the overall impact of 
exchange is not statistically different from zero (see Table 1010 in the Appendix for results using only Faculty of Law data). We even observe a slightly positive effect in the lower parts of the grade distribution (Figure 2-B in the Appendix). A possible explanation is in the selection of the curriculum at the host institution. When Law students go on exchange, they must select those courses that are most similar to the ones they would have taken at home in terms of content and course level. In case of a mismatch, the exchange student might not learn content that is essential for upcoming courses after the exchange. If this is the case, a mismatch results in lower grades after the exchange.

In contrast to the selection of the exchange curriculum at the Faculty of Law, at the Faculties of Economics and Business, Engineering and Science, students select a curriculum of exchange courses only after being selected to go. This might result in a less carefully selected curriculum for two reasons. As students are already selected for exchange, they are not induced to spend much time searching for the most similar courses. Second, especially for Master's students, universities offer a selective program of specific majors with highly specialized courses. A (Master's) student might thus be selected to go to a host institution where the courses offered differ from her own specialization. As a consequence, the probability of a mismatch between the courses taken abroad and those taught at home increases. At the Faculty of Law, the selection of courses at the host institution is part of the application process. If a student does not succeed in selecting similar courses, she is not allowed to go on exchange. This process suggests that law students are more likely to acquire the same knowledge during exchange as they would have obtained at home, which could explain why the impact of exchange on academic performance is more positive at the Law Faculty.

We also observe a strong positive effect for students leaving on exchange with the Erasmus program compared to mobile students leaving for a destination outside of Europe (see e.g. Table 5 columns (2)-(4)). We can think of several mechanisms that might explain this 
finding. First, as argued before, the European Commission has invested in the transparency and comparability of higher education programs and courses across Europe. These interventions might enable students to ensure a bitter fit between the courses on exchange and those at home.

Second, since the Erasmus exchange program has been launched in 1987, many of the European institutions have a long history of sending and receiving (European) exchange students. Mobile students might thus get more support and guidance when staying within Europe, because the exchange coordinators at European host institutions are more experienced. This could result in more learning during exchange, which might be reflected in better grades afterwards.

We also explored the possibility that cultural difference induces an important barrier to learning. If the cultural difference with European countries is smaller, compared to nonEuropean destinations, students staying in Europe might learn more during exchange. To estimate the impact of cultural distance on students' grade difference, we build a cultural distance index similar to Kogut and Singh's (1988) which is based on Hofstede's cultural dimensions (i.e., power distance, uncertainty avoidance, masculinity, and individualism) (Hofstede, 1980) and include this index to the main regression equation. The results show no significant impact of cultural distance on students' grade difference.

Students who leave on exchange to an institution that has a better ranking than the KU Leuven faculty experience a more negative effect of exchange on the difference in grades. If we believe that the quality of teaching is higher at a high ranked institute, then barriers to learning might be higher at a top university, since the courses the exchange student registers for build on previous knowledge that she might lack.

As a large number of students leaves on exchange and as this number is likely to increase over the next years (van der Wende, 2000), it is highly important to optimize the design of international student exchange programs. Building on our results and on the discussions we 
have had with the faculty exchange coordinators, we formulate some policy suggestions that might improve the effect of participation in exchange. Although our results are obtained for one university, KU Leuven, we believe that the policy implications might be valid for other institutions if the exchange program is organized similarly.

Our findings suggest a better outcome if the curriculum at the host institution is more similar to the one at home. Faculties should carefully screen possible exchange partners to enable that the courses offered are similar, both in terms of content and course weight. In addition, students are advised to carefully select the courses taken on exchange, so that the courses build on their previous knowledge and are also most comparable to the courses they would have taken at home in the absence of exchange.

\section{Conclusions}

We establish a causal link between participation in international student exchange programs and a student's academic performance. Our results provide evidence that exchange has, on average, a negative impact on students' difference in grades. Heterogeneity in the treatment effects reveal a less negative or zero impact for students at the Law Faculty, for Erasmus students, and for students leaving to a host institution that is not better ranked than the home faculty. The results survive a battery of robustness tests designed to gauge the effect of both observable and unobservable heterogeneity.

The presented analysis improves our understanding of how human capital formation is affected by the way tertiary education is executed. Education is an investment in human capital where the accumulation of knowledge and skills is reflected in a student's grades. While undoubtedly bringing other benefits, the design of current international exchange programs is likely to hurt formation of academic human capital according to our results. We should note however that this study does not aim to capture the overall impact of an international exchange 
program. Although we believe that academic performance is an important indicator of human capital and is therefore highly important to focus on, we also agree that exchange programs affect students in many (different) ways. Further research is thus necessary to obtain a better knowledge of the overall effect of international exchange programs, both in the short as well as in the long run. 


\section{References}

Becker, G. S. (1964). Human capital theory. Columbia, New York.

Becker, S. O., \& Ichino, A. (2002). Estimation of average treatment effects based on propensity scores. The Stata Journal, 2(4), 358-377.

Brandenburg, U., Berghoff, S., Taboadela, O., Bischof, L., Gajowniczek, J., Gehlke, A.,... Vancea, M.L. (2014). The Erasmus Impact study: Effects of mobility on the skills and employability of students and the internationalisation of higher education institutions. Luxembourg, Luxembourg: European Union.

Card, D. (2001). Estimating the return to schooling: Progress on some persistent econometric problems. Econometrica, 69(5), 1127-1160.

Cisneros-Donahue, T., Krentler, K. A., Reinig, B., \& Sabol, K. (2012). Assessing the Academic Benefit of Study Abroad. Journal of Education and Learning, 1(2), 169-178.

Debackere, K. (2000). Managing academic R\&D as a business at KU Leuven: context, structure and process. $R \& D$ Management, 30(4), 323-328.

Di Pietro, G. (2012). Does studying abroad cause international labor mobility? Evidence from Italy. Economic Letters, 117, 632-635.

Di Pietro, G. (2015). Do study abroad programs enhance the employability of graduates?. Education Finance and Policy, 10(2), 223-243.

European Commission (2015). Erasmus. Facts, Figures \& Trends. The European Union support for student and staff exchanges and university cooperation in 2013-2014, viewed October 18 2016 , http://ec.europa.eu/dgs/education_culture/repository/education/library/statistics/erasm us-plus-facts-figures_en.pdf. 
Hadis, B. F. (2005). Why are they better students when they come back? Determinants of academic focusing gains in the study abroad experience. Frontiers: The Interdisciplinary Journal of Study Abroad, 11, 57-70.

Heckman, J. J., Ichimura, H., \& Todd, P. (1998). Matching as an econometric evaluation estimator. The Review of Economic Studies, 65(2), 261-294.

Hofstede, G. (1980). Culture's consequences: International differences in work-related values. Beverly Hills: Sage Publications.

Kirkeboen, L. J., Leuven, E., \& Mogstad, M. (2016). Field of study, earnings, and self-selection. The Quarterly Journal of Economics, 131(3), 1057-1111.

Kogut, B., \& Singh, H. (1988). The effect of national culture on the choice of entry mode. Journal of international business studies, 19(3), 411-432.

Lange, F., \& Topel, R. (2006). The social value of education and human capital. Handbook of the Economics of Education, 1, 459-509.

Luo, J., \& Jamieson-Drake, D. (2015). Predictors of study abroad intent, participation, and college outcomes. Research in Higher Education, 56(1), 29-56.

Messer, D. \& Wolter, S. C. (2007). Are student exchange programs worth it? Higher Education, 54, 647-663.

Meya, J., \& Suntheim, K. (2014). The second dividend of studying abroad: The impact of international student mobility on academic performance. Cage Discussion Papers 215, Center for European Governance and Economic Development, University of Goettingen.

Mincer, J. (1958). Investment in human capital and personal income distribution. Journal of Political Economy, 66(4), 281-302. 
Parey, M. \& Waldinger, F. (2011). Studying abroad and the effect on international labour market mobility: evidence from the introduction of Erasmus. The Economic Journal, $121(551), 194-222$.

Rosenbaum, P. R., \& Rubin, D. B. (1983). The central role of the propensity score in observational studies for causal effects. Biometrika, 41-55.

Roth, P. L., \& Clarke, R. L. (1998). Meta-analyzing the relation between grades and salary. Journal of Vocational Behavior, 53(3), 386-400.

Sorrenti, G. (2017). The Spanish or the German apartment? Study abroad related outcomes and its recognition by the labour market. Economics of Education Review, 60, 142-158.

Spence, M. (1973). Job market signaling. The Quarterly Journal of Economics, 87(3), 355-374.

van der Wende, M. C. (2000). The Bologna Declaration: Enhancing the transparency and competitiveness of European higher education. Journal of Studies in International Education, 4(2), 3-10.

Wächter, B. (2004). The Bologna Process: developments and prospects. European Journal of Education, 39(3), 265-273.

West, A. (2001). Higher education admissions and student mobility within the EU: ADMIT, Clare Market Papers (18), London School of Economics and Political Science, Centre for Educational Research, London, UK.

Wiers-Jenssen, J. (2011). Background and employability of mobile vs. non-mobile students. Tertiary Education and Management, 17(2), 79-100. 


\section{Appendix}

Table A.1. Descriptive statistics of international exchange programs

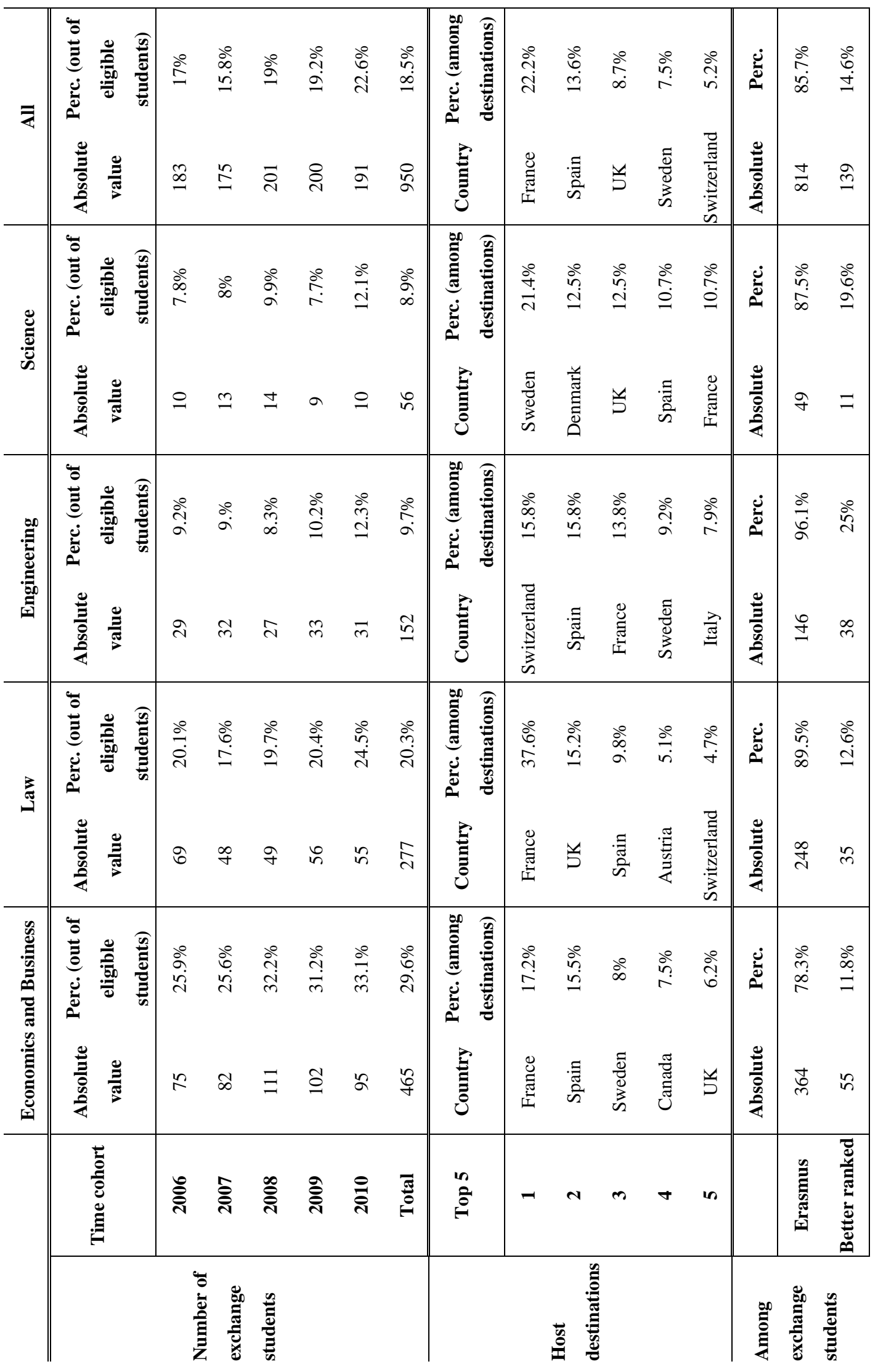


Table A.2. Grades during the exchange period

\begin{tabular}{|c|c|c|c|c|c|c|c|c|c|c|}
\hline \multirow[b]{2}{*}{ Faculty } & \multicolumn{4}{|c|}{ Mobile students } & \multicolumn{4}{|c|}{ Non-mobile students } & \multicolumn{2}{|c|}{$\begin{array}{l}\text { Diff. mobile and } \\
\text { non-mobile } \\
\text { students }\end{array}$} \\
\hline & Mean & Std.Dev. & Min & Max & Mean & Std.Dev. & Min & Max & Mean & Std.Er. \\
\hline $\begin{array}{l}\text { Economics } \\
\text { and Business }\end{array}$ & 75.57 & 10.65 & 18.57 & 94 & 64.26 & 12.28 & 13 & 94.55 & $-11.32 * * *$ & 0.62 \\
\hline Law & 73.23 & 10.19 & 28.73 & 93.25 & 63.96 & 9.53 & 0 & 81 & $-9.27 * * *$ & 0.71 \\
\hline Engineering & 64.03 & 9.31 & 0 & 82.97 & 68.06 & 9.83 & 0 & 90.58 & $4.04 * * *$ & 0.80 \\
\hline Science & 76.49 & 12.13 & 19 & 92.50 & 70.69 & 12.39 & 0 & 97.73 & $-5.80 * *$ & 1.70 \\
\hline $\begin{array}{l}\text { Notes: Grades d } \\
\text { Economics and } \\
* * * \mathrm{p}<0.01 \text {, ** }\end{array}$ & $\begin{array}{l}\text { g exchan } \\
\text { iness wh } \\
.05, * \mathrm{p}<\end{array}$ & $\begin{array}{l}\text { coincide wi } \\
\text { these are ec }\end{array}$ & $\begin{array}{l}\mathrm{h} \text { the gra } \\
\text { ual to the }\end{array}$ & $\begin{array}{l}\text { es in } 1^{\text {st }} \text { a } \\
\text { grades ob }\end{array}$ & $\begin{array}{l}\mathrm{d} / \text { or } 2^{\text {nd }} \mathrm{s} \\
\text { ined in th }\end{array}$ & hester of the & Mast & s year; e & $\begin{array}{l}\text { cept for the } \mathrm{F} \\
\text { s year. }\end{array}$ & culty of \\
\hline
\end{tabular}

Table A.3. Probability estimates of participation in an exchange program

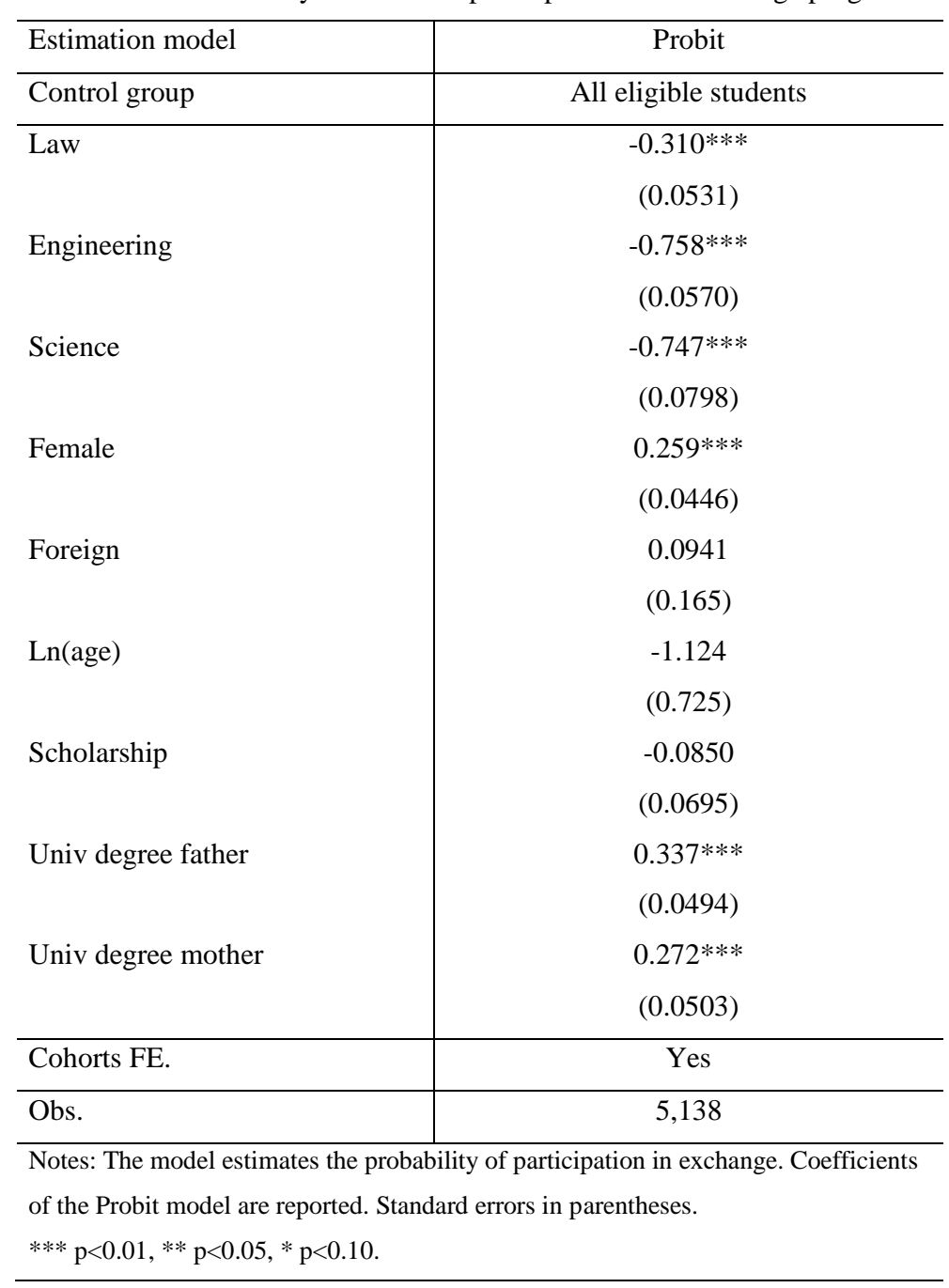


Table A.4. Pre-trends: difference in grades before treatment

\begin{tabular}{|c|c|c|c|c|c|c|}
\hline Faculty & All & All & $\begin{array}{c}\text { Economics } \\
\text { and Business }\end{array}$ & Law & Engineering & Science \\
\hline \multirow[t]{2}{*}{ Control group } & $\begin{array}{l}\text { All eligible } \\
\text { students }\end{array}$ & $\begin{array}{c}\text { Matched } \\
\text { observations }\end{array}$ & $\begin{array}{c}\text { Matched } \\
\text { observations }\end{array}$ & $\begin{array}{c}\text { Matched } \\
\text { observations }\end{array}$ & $\begin{array}{c}\text { Matched } \\
\text { observations }\end{array}$ & $\begin{array}{c}\text { Matched } \\
\text { observations }\end{array}$ \\
\hline & (1) & (2) & (3) & (4) & (5) & (6) \\
\hline Exchange & $\begin{array}{l}-0.279 \\
(0.387)\end{array}$ & $\begin{array}{l}-0.152 \\
(0.444)\end{array}$ & $\begin{array}{l}-0.633 \\
(0.448)\end{array}$ & $\begin{array}{c}0.800 \\
(0.501)\end{array}$ & $\begin{array}{l}-0.446 \\
(0.551)\end{array}$ & $\begin{array}{c}0.271 \\
(1.209)\end{array}$ \\
\hline Exch Law & $\begin{array}{c}0.842 \\
(0.574)\end{array}$ & $\begin{array}{c}0.722 \\
(0.665)\end{array}$ & & & & \\
\hline Exch Engineering & $\begin{array}{l}-0.498 \\
(0.606)\end{array}$ & $\begin{array}{l}-0.0628 \\
(0.726)\end{array}$ & & & & \\
\hline Exch Science & $\begin{array}{l}-0.792 \\
(1.135)\end{array}$ & $\begin{array}{l}-0.323 \\
(1.276)\end{array}$ & & & & \\
\hline Law & $\begin{array}{c}2.761 * * * \\
(0.290)\end{array}$ & $\begin{array}{c}2.864 * * * \\
(0.441)\end{array}$ & & & & \\
\hline Engineering & $\begin{array}{c}2.769 * * * \\
(0.266)\end{array}$ & $\begin{array}{c}2.329 * * * \\
(0.477)\end{array}$ & & & & \\
\hline Science & $\begin{array}{c}4.341 * * * \\
(0.393)\end{array}$ & $\begin{array}{c}3.883 * * * \\
(0.698)\end{array}$ & & & & \\
\hline Constant & $\begin{array}{c}-1.511^{* * * *} \\
(0.296)\end{array}$ & $\begin{array}{c}-1.239 * * * \\
(0.452)\end{array}$ & $\begin{array}{l}-0.548 \\
(0.660)\end{array}$ & $\begin{array}{c}0.474 \\
(0.591)\end{array}$ & $\begin{array}{l}-0.118 \\
(0.725)\end{array}$ & $\begin{array}{l}2.619 * \\
(1.577)\end{array}$ \\
\hline $\begin{array}{l}\text { SES (F) FE. } \\
\text { Cohorts FE. }\end{array}$ & $\begin{array}{l}\text { Yes } \\
\text { Yes }\end{array}$ & $\begin{array}{l}\text { Yes } \\
\text { Yes }\end{array}$ & $\begin{array}{l}\text { Yes } \\
\text { Yes }\end{array}$ & $\begin{array}{l}\text { Yes } \\
\text { Yes }\end{array}$ & $\begin{array}{l}\text { Yes } \\
\text { Yes }\end{array}$ & $\begin{array}{l}\text { Yes } \\
\text { Yes }\end{array}$ \\
\hline Obs. & 5,131 & 2,181 & 963 & 641 & 397 & 152 \\
\hline
\end{tabular}


Table A.5. Ranking host institution

\begin{tabular}{|c|c|c|c|c|}
\hline Faculty & Ranking & $\begin{array}{l}\text { Ranking } \\
\text { Faculty } \\
\mathrm{KU} \\
\text { Leuven }\end{array}$ & $\begin{array}{l}\text { Host institution is better ranked } \\
\text { if... }\end{array}$ & $\begin{array}{l}\text { Nr of } \\
\text { better } \\
\text { ranked } \\
\text { host inst. }\end{array}$ \\
\hline $\begin{array}{l}\text { Economics } \\
\text { and } \\
\text { Business }\end{array}$ & $\begin{array}{l}\text { QS Subject Business \& Management, } 2016 \\
\text { QS Subject Economics \& Econometrics, } \\
2016 \\
\text { Shanghai Subject of Economics, } 2015 \\
\text { BS Europe } 2015\end{array}$ & $\begin{array}{l}51-100 \\
51-100 \\
101-150\end{array}$ & $\begin{array}{l}\text { QS SubjBusManagement }<50 \\
\& \\
\text { QS SubjEconEconometrics }<50 \\
\& \\
\text { Sha SubjEcon }<100 \\
\text { OR } \\
\text { BS Europe }<30\end{array}$ & $128(12 \%)$ \\
\hline Law & QS Subject Law, 2016 & 33 & QS SubjLaw < 30 & $61(10 \%)$ \\
\hline Engineering & $\begin{array}{l}\text { Shanghai Field of Engineering, } 2015 \\
\text { QS Faculty Engineering \& Technology, } \\
2015\end{array}$ & $\begin{array}{l}51-75 \\
74\end{array}$ & $\begin{array}{l}\text { Sha FieldEng_ma1 }<50 \& \\
\text { QS FacEngTech_ma1 }<60\end{array}$ & $53(23 \%)$ \\
\hline Science & $\begin{array}{l}\text { Shanghai Field Life \& Agricultural } \\
\text { Sciences, } 2015 \\
\text { Shanghai Field of Science, } 2015 \\
\text { QS Faculty Natural Sciences, } 2015\end{array}$ & $\begin{array}{l}51-75 \\
151-200 \\
92\end{array}$ & $\begin{array}{l}\text { Sha FieldAgrLifeScience }<50 \\
\& \\
\text { Sha FieldScience }<150 \& \\
\text { QS FacNaturalsciences }<80\end{array}$ & $24(18 \%)$ \\
\hline
\end{tabular}

Notes: Overview ranking KU Leuven, and construction of 'better ranked' variable for main analysis 
Table 7. Impact of exchange on the student's level of achievement

\begin{tabular}{l|ccc}
\hline & $\begin{array}{c}\text { Level of distinction } \\
\text { increased }\end{array}$ & $\begin{array}{c}\text { Level of distinction } \\
\text { decreased }\end{array}$ & $\begin{array}{c}\text { No impact on level of } \\
\text { distinction }\end{array}$ \\
\hline All students & 28 & 115 & 807 \\
& $(3 \%)$ & $(12.1 \%)$ & $(85 \%)$ \\
\hline Economics and Business & 12 & 39 & 414 \\
\hline Law & $(2.6 \%)$ & $(8.4 \%)$ & $(89 \%)$ \\
\hline Engineering & 16 & 7 & 254 \\
\hline Science & $(5.8 \%)$ & $(2.5 \%)$ & $(91.7 \%)$ \\
& $(0 \%)$ & $(26.3 \%)$ & $(73.7 \%)$ \\
\hline
\end{tabular}

Note: The percentage reflects the relative number among exchange students 
Table 8. DiD estimation results. Relative difference in grades before and after exchange

\begin{tabular}{|c|c|c|c|c|}
\hline $\begin{array}{l}\text { Estimation model } \\
\text { Control group }\end{array}$ & $\begin{array}{c}\text { CDiD } \\
\text { Matched observations }\end{array}$ & $\begin{array}{c}\text { CDiD } \\
\text { Matched observations }\end{array}$ & $\begin{array}{c}\text { DiD } \\
\text { Applicants } \\
\text { (FEB \& Law) }\end{array}$ & $\begin{array}{c}\text { DiD } \\
\text { All eligible students }\end{array}$ \\
\hline & (1) & (2) & (3) & (4) \\
\hline Exchange & $\begin{array}{l}-0.0148^{*} \\
(0.00878)\end{array}$ & $\begin{array}{c}-0.0723 * * * \\
(0.0193)\end{array}$ & $\begin{array}{c}-0.0699 * * * \\
(0.0210)\end{array}$ & $\begin{array}{c}-0.0638 * * * \\
(0.0164)\end{array}$ \\
\hline Exch Law & $\begin{array}{c}0.0331 * * \\
(0.0133)\end{array}$ & $\begin{array}{c}0.0317 \\
(0.0200)\end{array}$ & $\begin{array}{c}0.0163 \\
(0.0291)\end{array}$ & $\begin{array}{l}0.0262 * \\
(0.0134)\end{array}$ \\
\hline Exch Engineering & $\begin{array}{l}-0.0259 \\
(0.0175)\end{array}$ & $\begin{array}{l}-0.0310 \\
(0.0255)\end{array}$ & & $\begin{array}{c}-0.0345^{*} \\
(0.0179)\end{array}$ \\
\hline Exch Science & $\begin{array}{l}-0.0497 * \\
(0.0282)\end{array}$ & $\begin{array}{l}-0.0509 \\
(0.0403)\end{array}$ & & $\begin{array}{c}-0.0620 * * \\
(0.0285)\end{array}$ \\
\hline Law & $\begin{array}{l}-0.00387 \\
(0.00662)\end{array}$ & $\begin{array}{l}-0.00907 \\
(0.0162)\end{array}$ & $\begin{array}{l}0.00957 \\
(0.0266)\end{array}$ & $\begin{array}{l}-0.00333 \\
(0.00662)\end{array}$ \\
\hline Engineering & $\begin{array}{c}0.0396 * * * \\
(0.00670)\end{array}$ & $\begin{array}{c}0.0437 * * \\
(0.0194)\end{array}$ & & $\begin{array}{c}0.0398 * * * \\
(0.00670)\end{array}$ \\
\hline Science & $\begin{array}{l}0.121 * * * \\
(0.00890)\end{array}$ & $\begin{array}{c}0.112 * * * \\
(0.0301)\end{array}$ & & $\begin{array}{l}0.121 * * * \\
(0.00890)\end{array}$ \\
\hline Exchange final year & $\begin{array}{c}0.0276 * * * \\
(0.00754)\end{array}$ & $\begin{array}{c}0.0448 * * * \\
(0.0134)\end{array}$ & $\begin{array}{c}0.0452 * * * \\
(0.0130)\end{array}$ & $\begin{array}{c}0.0296 * * * \\
(0.00750)\end{array}$ \\
\hline Female & $\begin{array}{c}0.0233 * * * \\
(0.00482)\end{array}$ & $\begin{array}{c}0.0390 * * * \\
(0.00880)\end{array}$ & $\begin{array}{c}0.0307 * * * \\
(0.0106)\end{array}$ & $\begin{array}{c}0.0225 * * * \\
(0.00482)\end{array}$ \\
\hline Erasmus & & $\begin{array}{c}0.0641 * * * \\
(0.0168)\end{array}$ & $\begin{array}{c}0.0626 * * * \\
(0.0176)\end{array}$ & $\begin{array}{c}0.0654 * * * \\
(0.0167)\end{array}$ \\
\hline Better ranked & & $\begin{array}{l}-0.0180 \\
(0.0168)\end{array}$ & $\begin{array}{l}-0.0355^{*} \\
(0.0204)\end{array}$ & $\begin{array}{l}-0.0213 \\
(0.0166)\end{array}$ \\
\hline Constant & $\begin{array}{c}0.212 * * * \\
(0.0170)\end{array}$ & $\begin{array}{c}0.210 * * * \\
(0.0170)\end{array}$ & $\begin{array}{c}0.209 * * * \\
(0.0207)\end{array}$ & $\begin{array}{l}0.196 * * * \\
(0.00743)\end{array}$ \\
\hline $\begin{array}{l}\text { SES (F) FE. } \\
\text { Cohorts FE. }\end{array}$ & $\begin{array}{l}\text { Yes } \\
\text { Yes }\end{array}$ & $\begin{array}{l}\text { Yes } \\
\text { Yes }\end{array}$ & $\begin{array}{l}\text { Yes } \\
\text { Yes }\end{array}$ & $\begin{array}{l}\text { Yes } \\
\text { Yes }\end{array}$ \\
\hline Obs. & 1,435 & 1,435 & 920 & 5,138 \\
\hline
\end{tabular}


Table A.8. Likelihood of obtaining a Master's degree

\begin{tabular}{l|c|c}
\hline Estimation model & Probit & Probit \\
\hline Control group & All eligible students & All eligible students \\
\hline Exchange & $-0.0467 * * *$ & $-0.0397 * * *$ \\
Better ranked & $(0.0123)$ & $(0.0126)$ \\
& & $-0.0530^{* *}$ \\
Bachelor's grade & 0.000954 & $(0.0230)$ \\
& $(0.000829)$ & 0.00132 \\
Female & $0.0366^{* * *}$ & $(0.000845)$ \\
& $(0.0119)$ & $0.0355^{* * *}$ \\
Foreign & $-0.412^{* * *}$ & $(0.0119)$ \\
& $(0.153)$ & $-0.415^{* * *}$ \\
Ln(Age) & $-0.0467 * * *$ & $(0.152)$ \\
& $(0.0123)$ & $-0.0397 * * *$ \\
\hline Cohorts FE. & Yes & $(0.0126)$ \\
\hline Obs. & 1,605 & 1,605 \\
\hline Notes: Analysis is restricted to students of the Faculty of Economics and Business. The dependent \\
variable is a dummy equal to one if the student obtained a Master's degree at KU Leuven. Marginal \\
effects are reported. Standard errors in parentheses. *** p<0.01, ** p<0.05, * p<0.10. \\
\hline
\end{tabular}


Table 9. DiD estimation results - Faculty of Economics and Business

\begin{tabular}{|c|c|c|c|c|c|}
\hline Estimation model & CDiD & CDiD & DiD & Heckman & DiD \\
\hline \multirow[t]{2}{*}{ Control group } & Matched obs. & Matched obs. & Only applicants & $\begin{array}{l}\text { All eligible } \\
\text { students (*) }\end{array}$ & $\begin{array}{c}\text { All eligible } \\
\text { students }\end{array}$ \\
\hline & (1) & (3) & (4) & (5) & (6) \\
\hline Exchange & $\begin{array}{l}-1.064 * \\
(0.644)\end{array}$ & $\begin{array}{c}-4.074 * * * \\
(0.887)\end{array}$ & $\begin{array}{c}-4.510 * * * \\
(0.908)\end{array}$ & $\begin{array}{c}-4.157 * * * \\
(0.733)\end{array}$ & $\begin{array}{c}-4.063 * * * \\
(0.734)\end{array}$ \\
\hline Exchange final year & $\begin{array}{c}0.223 \\
(0.621)\end{array}$ & $\begin{array}{c}0.751 \\
(0.592)\end{array}$ & $\begin{array}{c}0.457 \\
(0.574)\end{array}$ & $\begin{array}{c}1.223 * * * \\
(0.402)\end{array}$ & $\begin{array}{c}1.030 * * * \\
(0.364)\end{array}$ \\
\hline Female & & $\begin{array}{l}1.387 * * \\
(0.585)\end{array}$ & $\begin{array}{c}1.625 * * * \\
(0.604)\end{array}$ & $\begin{array}{c}1.711 * * * \\
(0.360)\end{array}$ & $\begin{array}{c}1.357 * * * \\
(0.347)\end{array}$ \\
\hline Erasmus & & $\begin{array}{c}4.029 * * * \\
(0.772)\end{array}$ & $\begin{array}{c}3.914 * * * \\
(0.778)\end{array}$ & $\begin{array}{c}3.809 * * * \\
(0.760)\end{array}$ & $\begin{array}{c}4.188 * * * \\
(0.768)\end{array}$ \\
\hline Better ranked & & $\begin{array}{c}-1.830 * \\
(1.069)\end{array}$ & $\begin{array}{c}-1.851 * \\
(1.064)\end{array}$ & $\begin{array}{c}-2.257 * * \\
(0.970)\end{array}$ & $\begin{array}{c}-1.784 * \\
(1.061)\end{array}$ \\
\hline Constant & $\begin{array}{c}7.049 * * * \\
(1.060)\end{array}$ & $\begin{array}{c}6.980 * * * \\
(1.043)\end{array}$ & $\begin{array}{c}7.597 * * * \\
(1.153)\end{array}$ & $\begin{array}{c}7.246 * * * \\
(0.477)\end{array}$ & $\begin{array}{c}7.535^{* * *} \\
(0.491)\end{array}$ \\
\hline $\begin{array}{l}\text { SES (F) FE. } \\
\text { Cohorts FE. }\end{array}$ & $\begin{array}{l}\text { Yes } \\
\text { Yes }\end{array}$ & $\begin{array}{l}\text { Yes } \\
\text { Yes }\end{array}$ & $\begin{array}{l}\text { Yes } \\
\text { Yes }\end{array}$ & $\begin{array}{l}\text { Yes } \\
\text { Yes }\end{array}$ & $\begin{array}{l}\text { Yes } \\
\text { Yes }\end{array}$ \\
\hline Obs. & 625 & 625 & 594 & 1,605 & 1,569 \\
\hline $\begin{array}{l}\text { Notes: The dependent } \\
\text { Estimation model DiD: } \\
* * * p<0.01, * * \mathrm{p}<0.05\end{array}$ & $\begin{array}{l}\text { lable is the differ } \\
\text { ference-in-differ } \\
0<0.1 \text {. (*) Samp }\end{array}$ & $\begin{array}{l}\text { in grades after } \\
\text { e regression; est } \\
\text { acludes all stude }\end{array}$ & $\begin{array}{l}\text { id before exchange } \\
\text { tion model CDiD: } \\
\text { that obtained a Bac }\end{array}$ & $\begin{array}{l}\text { d. Robust stan } \\
\text { tional differenc } \\
\text { 's degree. }\end{array}$ & $\begin{array}{l}\text { ors in parenthe } \\
\text { erence regress }\end{array}$ \\
\hline
\end{tabular}


Table 1010. DiD estimation results - Faculty of Law

\begin{tabular}{|c|c|c|c|c|}
\hline Estimation model & CDiD & CDiD & DiD & $\mathrm{DiD}$ \\
\hline \multirow[t]{2}{*}{ Control group } & Matched obs. & Matched obs. & Only applicants & All eligible students \\
\hline & (1) & (2) & (3) & (4) \\
\hline \multirow[t]{2}{*}{ Exchange } & 0.455 & -2.367 & -2.465 & -2.850 \\
\hline & $(0.700)$ & $(2.679)$ & $(2.837)$ & $(2.707)$ \\
\hline \multirow[t]{2}{*}{ Exchange final year } & $2.835 * *$ & $2.949 * *$ & $5.715^{* * *}$ & $3.758 * * *$ \\
\hline & $(1.230)$ & (1.240) & (1.786) & $(0.706)$ \\
\hline \multirow[t]{2}{*}{ Female } & 0.584 & 0.464 & -0.0373 & 0.0998 \\
\hline & $(0.713)$ & $(0.700)$ & $(0.838)$ & $(0.410)$ \\
\hline \multirow[t]{2}{*}{ Erasmus } & & 3.360 & 3.468 & 3.436 \\
\hline & & $(2.562)$ & (2.559) & $(2.650)$ \\
\hline \multirow[t]{2}{*}{ Better ranked } & & -1.408 & -1.494 & -1.980 \\
\hline & & $(1.885)$ & (1.916) & (1.936) \\
\hline \multirow[t]{2}{*}{ Constant } & $9.189 * * *$ & $9.067 * * *$ & $9.462 * * *$ & $7.953 * * *$ \\
\hline & $(1.055)$ & $(1.046)$ & $(1.416)$ & $(0.557)$ \\
\hline SES (F) FE. & Yes & Yes & Yes & Yes \\
\hline Cohorts FE. & Yes & Yes & Yes & Yes \\
\hline Obs. & 415 & 415 & 326 & 1,365 \\
\hline \multicolumn{5}{|c|}{ Notes: The dependent variable is the difference in grades after and before exchange period. Robust standard errors in parentheses } \\
\hline \multicolumn{5}{|c|}{ Estimation model DiD: difference-in-difference regression; CDiD: conditional difference-in-difference regression. } \\
\hline
\end{tabular}


Table 11. DiD estimation results - Faculty of Engineering

\begin{tabular}{l|c|c|c}
\hline Estimation model & CDiD & CDiD & DiD \\
\hline Control group & Matched obs. & Matched obs. & All eligible students \\
\hline & $(1)$ & $(2)$ & -2.877 \\
\hline Exchange & $-2.212^{* *}$ & -2.837 & $(2.700)$ \\
Exchange final year & $(0.882)$ & $(2.873)$ & $-5.629 * * *$ \\
& -6.970 & -7.209 & $(0.791)$ \\
Female & $(4.903)$ & $(4.876)$ & $1.638^{* * *}$ \\
& $2.967 * * *$ & $2.983 * * *$ & $(0.427)$ \\
Erasmus & $(0.905)$ & $(0.909)$ & 0.685 \\
& & 0.989 & $(2.752)$ \\
Better ranked & & $(2.843)$ & -1.121 \\
& & -1.379 & $(1.218)$ \\
Constant & & $(1.253)$ & $8.757^{* * *}$ \\
& & $8.217 * * *$ & $(0.536)$ \\
\hline SES (F) FE. & $(1.518)$ & $(1.533)$ & Yes \\
Cohorts FE. & Yes & Yes & Yes \\
\hline Obs. & Yes & Yes & 1,573 \\
\hline Notes: The dependent variable is the difference in grades after and before exchange period. Robust standard errors in parentheses. & \\
Estimation model DiD: difference-in-difference regression; CDiD: conditional difference-in-difference regression. & \\
\hline & & & \\
\hline
\end{tabular}


Table A.12. DiD estimation results - Faculty of Science

\begin{tabular}{l|c|c|c}
\hline Estimation model & CDiD & CDiD & DiD \\
\hline Control group & Matched obs. & Matched obs. & All eligible students \\
\hline Exchange & $(1)$ & $(2)$ & $(3)$ \\
& -3.124 & -3.195 & $(1.326)$ \\
Exchange final year & $(2.024)$ & $(2.100)$ & 1.587 \\
& -1.606 & -1.634 & $(1.432)$ \\
Female & $(4.169)$ & $(4.173)$ & 0.496 \\
& -1.027 & -1.032 & $(0.706)$ \\
Better ranked & $(2.220)$ & $(2.236)$ & 0.0142 \\
& & 0.347 & $(2.406)$ \\
Constant & $15.99 * * *$ & $(3.025)$ & $13.61 * * *$ \\
& $(2.846)$ & $16.02 * * *$ & $(0.950)$ \\
\hline SES (F) FE. & Yes & $(2.870)$ & Yes \\
Cohorts FE. & Yes & Yes & Yes \\
\hline Obs. & 121 & 121 & 631 \\
\hline Notes: The dependent variable is the difference in grades after and before exchange period. Robust standard errors in parentheses. \\
Estimation model DiD: difference-in-difference regression; CDiD: conditional difference-in-difference regression. All students that \\
went on exchange left for a destination that is part of the Erasmus program. *** p<0.01,**p<0.05, * p<0.1. \\
\hline
\end{tabular}


Figure A.1. Kernel density plot: Grade distribution mobile and non-mobile students

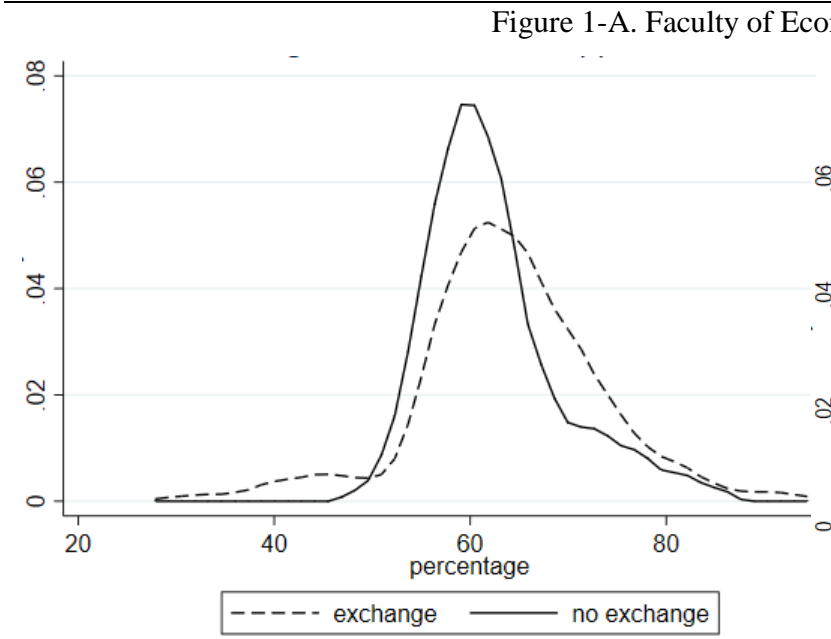

Grade distribution before application into exchange

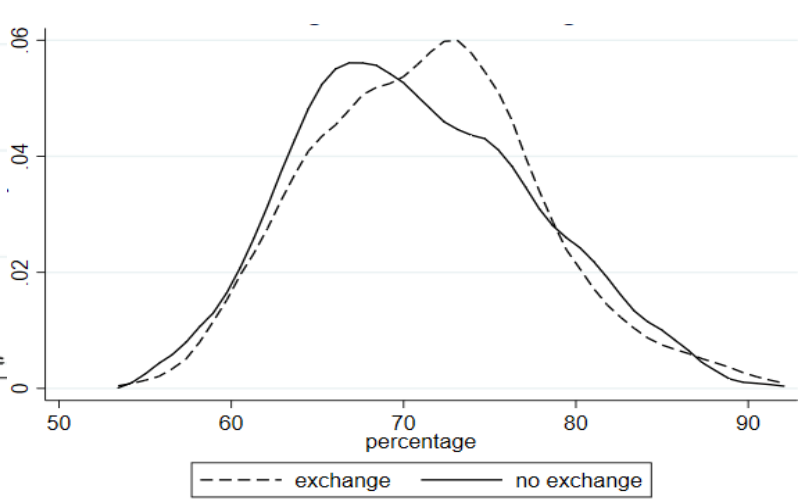

Grade distribution after exchange

Figure 1-B. Faculty of Law

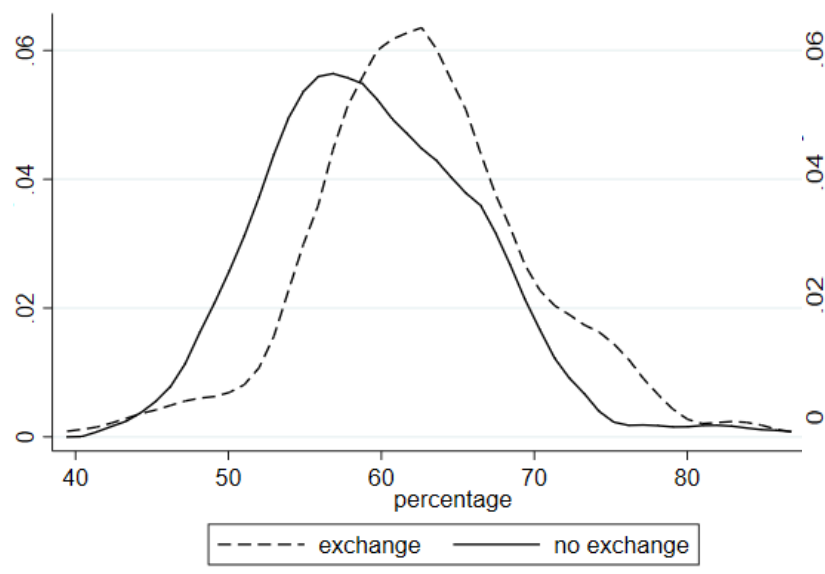

Grade distribution before application into exchange

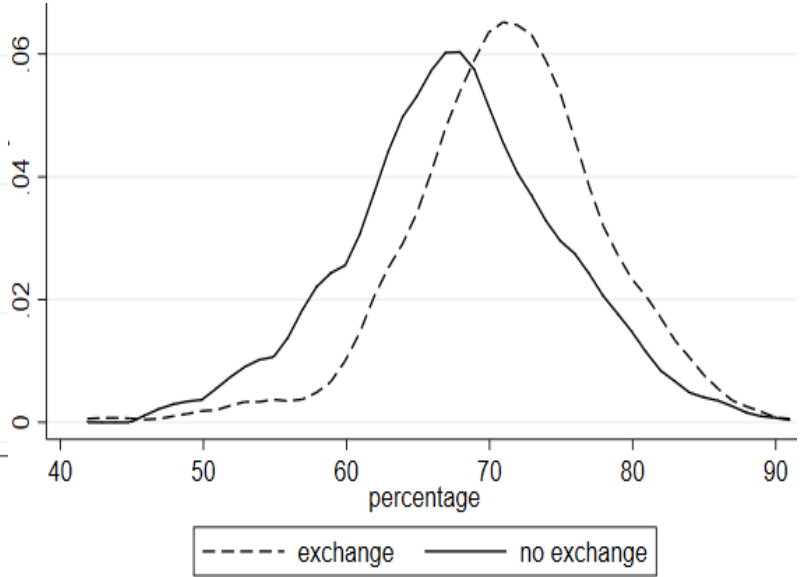

Grade distribution after exchange

Figure 1-C. Faculty of Engineering

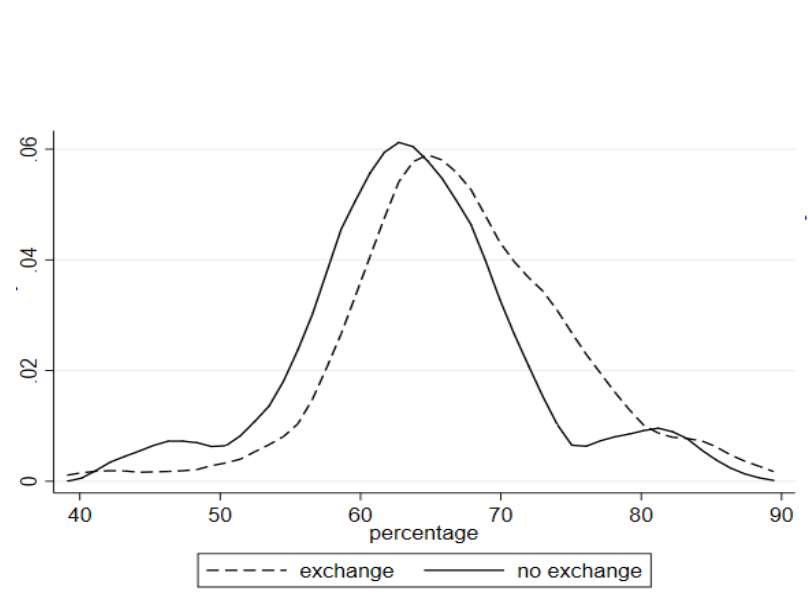

Grade distribution before application into exchange

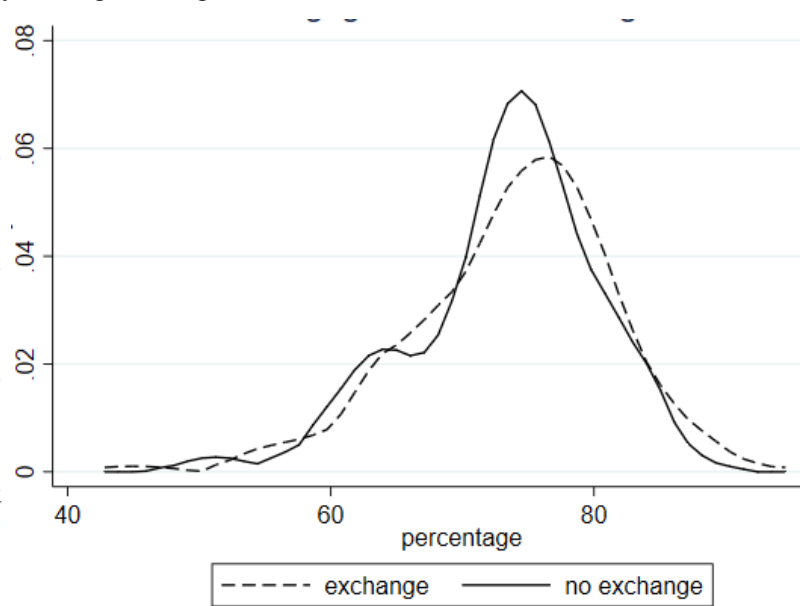

Grade distribution after exchange 
Figure 1-D. Faculty of Science

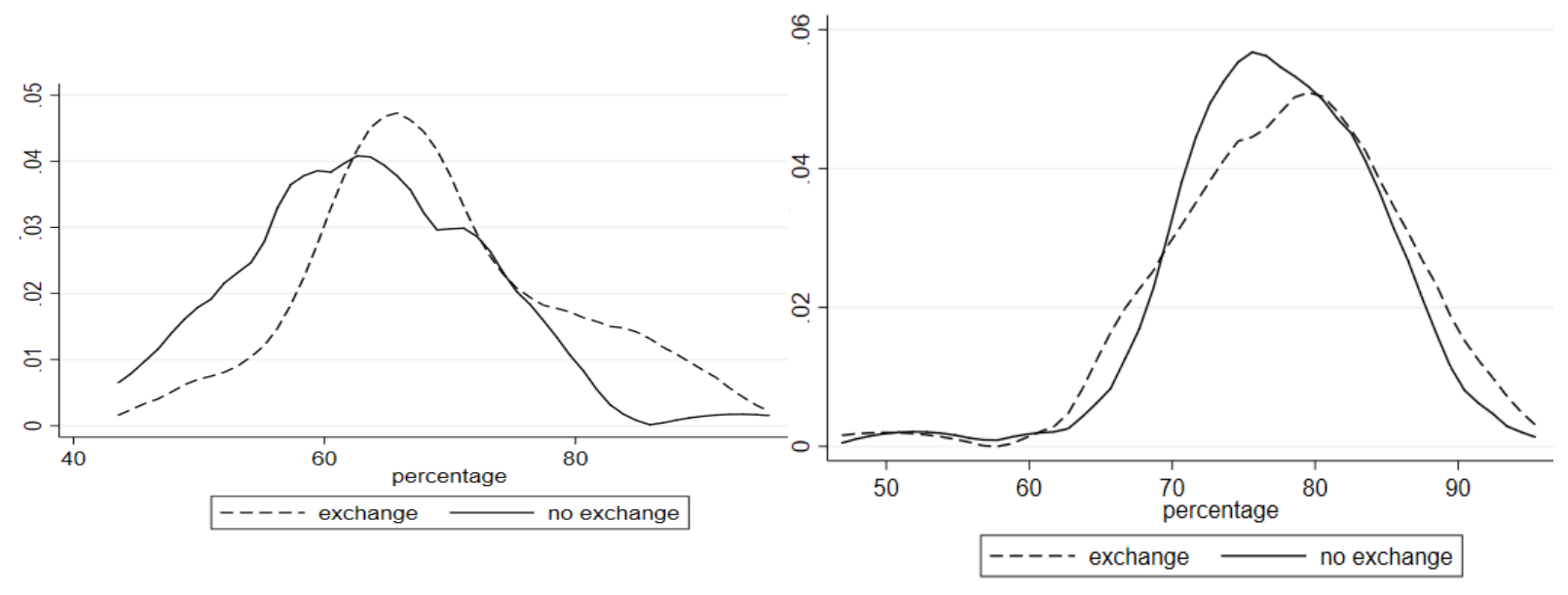

Grade distribution before application into exchange

Grade distribution after exchange

Note: the vertical axis represents density levels; the horizontal axis represents the grade percentage. The sample contains all matched observations (treated and non-treated), but excludes students that went on exchange in the final Master's year 
Figure A.2. Estimation results quantile regressions

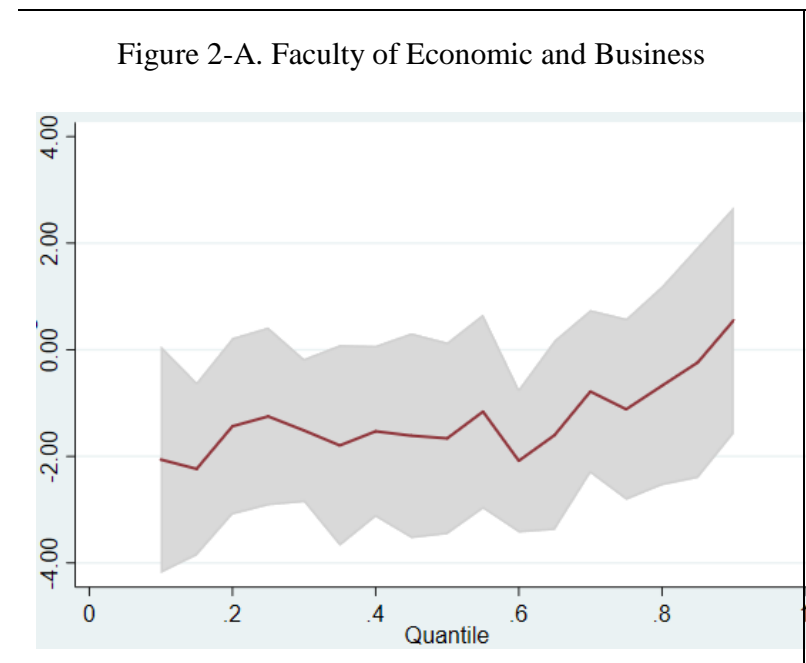

Figure 2-C. Faculty of Engineering

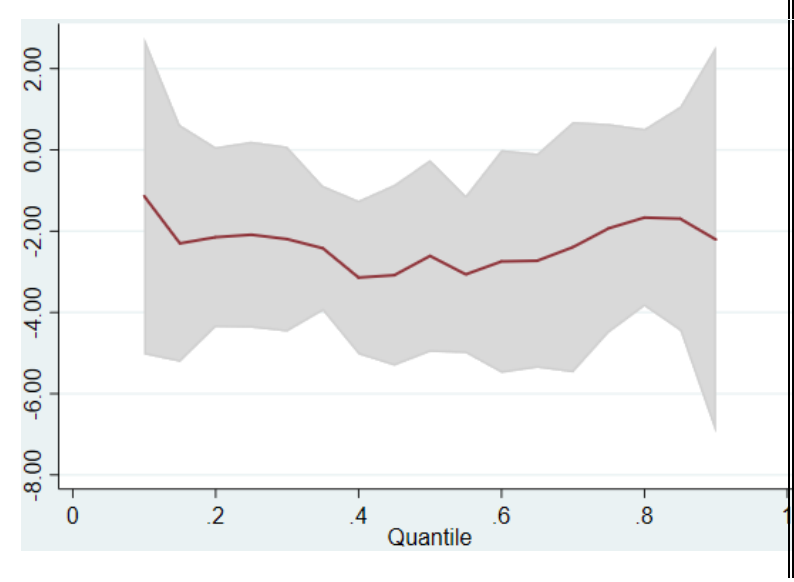

Figure 2-B. Faculty of Law

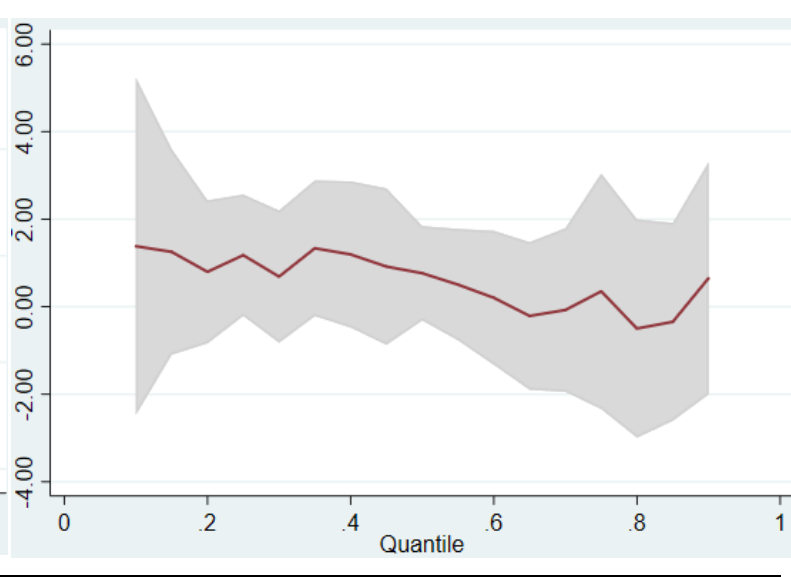

Figure 2-D. Faculty of Science

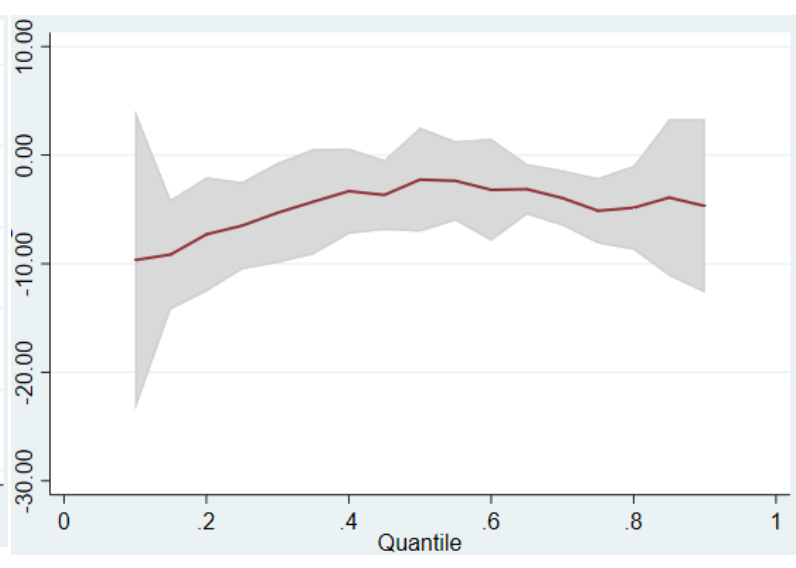


MANAGEMENT, STRATEGY AND INNOVATION (MSI) Naamsestraat 69 bus 3535

3000 LEUVEN, Belgium

$$
\text { tel. + } 3216326700
$$

msi@econ.kuleuven.be

https://feb.kuleuven.be/research/MSI/ 